\title{
CLIMATE CHANGE DISCLOSURE: AN EMPIRICAL STUDY ON THE OIL \& GAS COMPANIES LISTED ON TORONTO STOCK EXCHANGE (TSX)
}

by

\author{
Amirus Salat \\ MBA (1999), University of Dhaka \\ BBA (1998), University of Dhaka
}

\begin{abstract}
A thesis
presented to Ryerson University

in partial fulfillment of the

requirements for the degree of

Master of Science in Management

in the program of

Master of Science in Management
\end{abstract}

Toronto, Ontario, Canada, 2019

(C) Amirus Salat, 2019 


\section{AUTHOR'S DECLARATION FOR ELECTRONIC SUBMISSION OF A THESIS}

I hereby declare that I am the sole author of this thesis. This is a true copy of the thesis, including any required final revisions, as accepted by my examiners.

I authorize Ryerson University to lend this thesis to other institutions or individuals for the purpose of scholarly research.

I further authorize Ryerson University to reproduce this thesis by photocopying or by other means, in total or in part, at the request of other institutions or individuals for the purpose of scholarly research.

I understand that my thesis may be made electronically available to the public. 


\title{
"CLIMATE CHANGE DISCLOSURE: AN EMPIRICAL STUDY ON THE OIL \& GAS COMPANIES LISTED ON TORONTO STOCK EXCHANGE (TSX)"
}

\author{
Student Name: Amirus Salat \\ Degree: Master of Science in Management \\ Program: Master of Science in Management \\ University: Ryerson University
}

Year: 2019

\begin{abstract}
This research investigates the current state of disclosure on the climate change issues of the oil \& gas companies listed on the Toronto Stock Exchange (TSX). Using a sample of 58 companies, I conduct a content analysis of their publicly available documents and develop a disclosure index. The study demonstrates that there is a significant association between the level of disclosure of climate change issues (disclosures index) and the board of director's effectiveness (measured by Board Shareholder Confidence Index) for Canadian oil \& gas companies. This study also explores the association between firms' value and the level of climate change disclosure. The empirical evidence indicates that the investors take the extent of disclosures on climate changes into considerations when they assess the market value of the firms. This study contributes to environmental accounting literature because it examines the relationship between climate change disclosures and corporate governance. From a practical point of view, the outcome of this analysis will help Canadian Securities Administrator (CSA) to have insight into climate change disclosures practices and provides a frame of references for developing related disclosures requirement.
\end{abstract}




\section{Acknowledgments}

First of all, I would like to express my profound gratitude to my supervisor Dr. Margaret Plaza, for her support and encouragement throughout my master's program. I am deeply indebted for her excellent direction and support that I have received throughout the research process. It is my privilege to have her as my supervisor.

I would also like to convey my gratitude to Dr. Thomas Schneider and Dr. Hong Yu for serving as my thesis committee members. In particular, I thank Dr. Thomas who provided me with a good amount of papers related to my thesis. I am grateful to Monzur Hossain and Mahfuzul Haq Chowdhury for their valuable advice regarding my thesis. I want to thank Dr. Dewan Mahboob Hossain for being my research mentor; I was blessed with his constant help and guidance.

Finally, I want to acknowledge the support, patience, and encouragement provided by my family. Most importantly, I wish to thank my loving and supportive wife, Tanzina, who has been with me every step of the way, provided me with friendship and an extraordinary level of support, encouragement, and understanding during this endeavor. 


\section{Table of Contents}

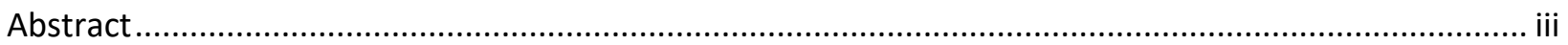

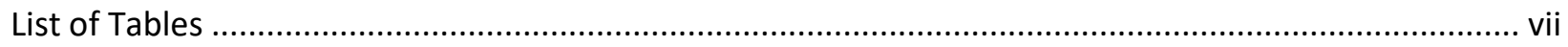

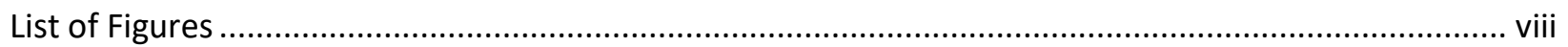

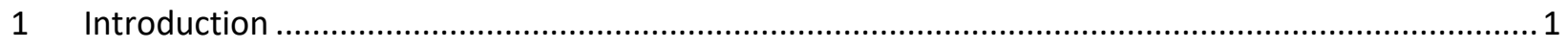

1.1. Research questions and research objectives:....................................................................

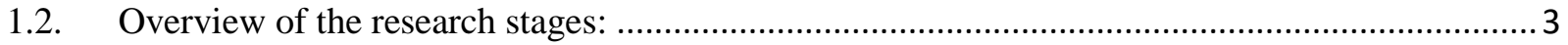

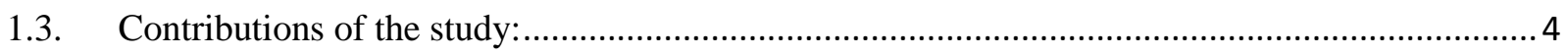

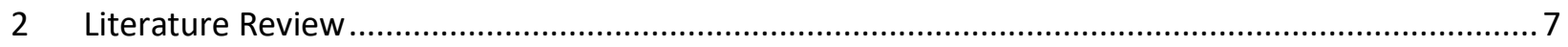

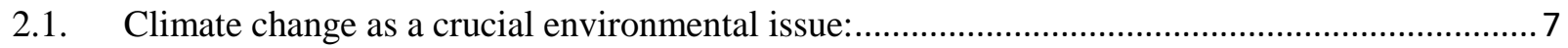

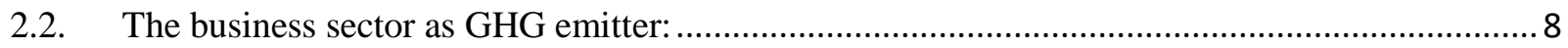

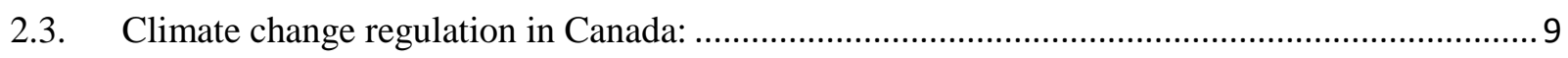

2.4. Climate change-related disclosures framework: ............................................................. 10

2.4.1. International climate change-related disclosures framework:.....................................10

2.4.2. Climate change reporting framework in Canada: ....................................................... 11

2.5. Prior research on climate change-related disclosures ........................................................ 12

2.5.1. Research on climate change- related disclosures levels (Stream 1) ................................13

2.5.2. Research on the determinants of climate change disclosures (Stream 2): .....................13

2.5.3. Research finding the relationship between climate change disclosures and firm values: .14

2.5.4. Prior research on climate change-related disclosures of Canada.....................................16

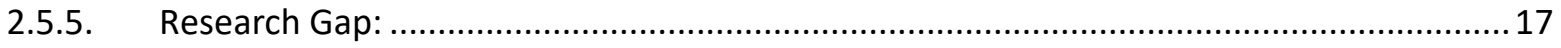

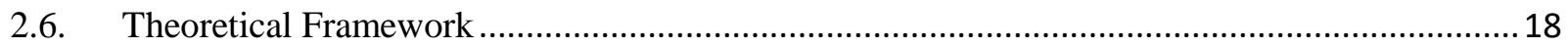

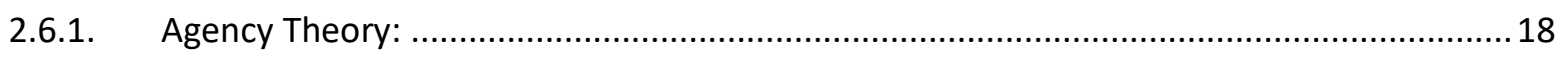

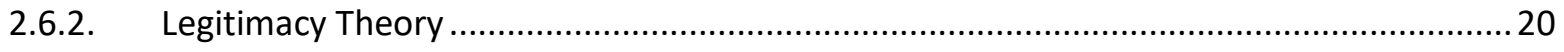

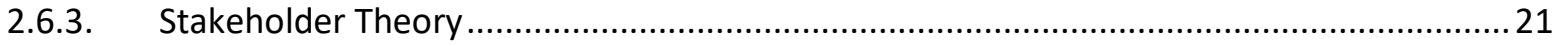

2.6.4. A combination of the theoretical framework of this research ..........................................22

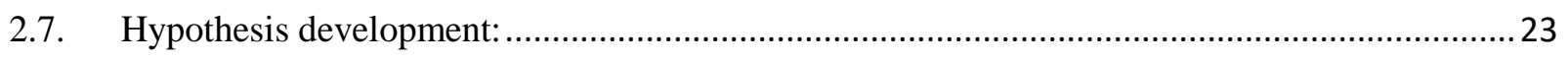

2.7.1. Board effectiveness and climate change disclosures: .................................................23

2.7.2. Climate change disclosures and firm value:............................................................... 25

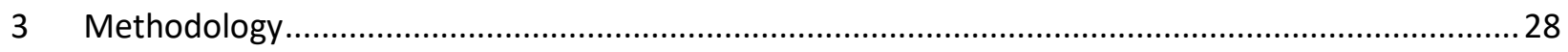

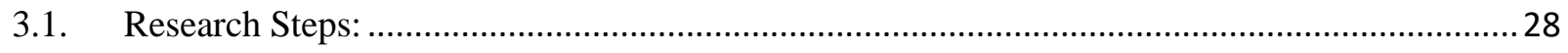




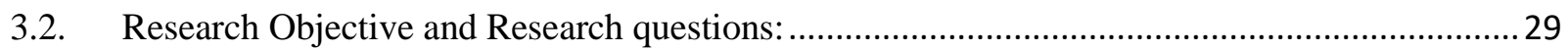

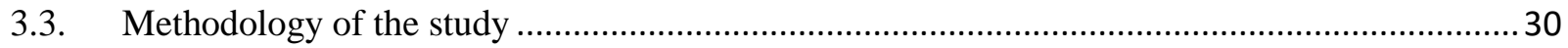

3.3.1. Stage One: Development of the Disclosure Index: ....................................................... 30

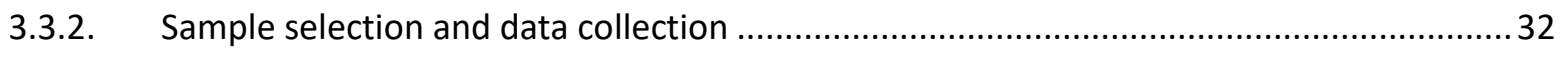

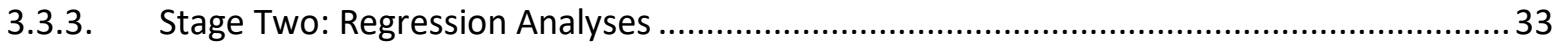

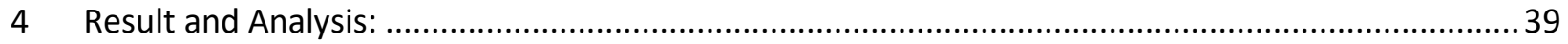

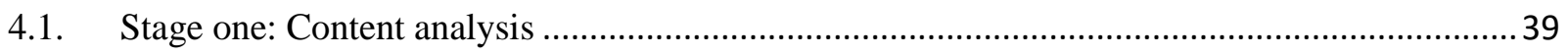

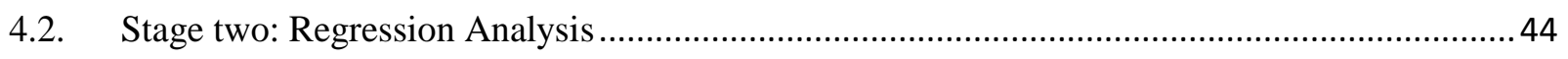

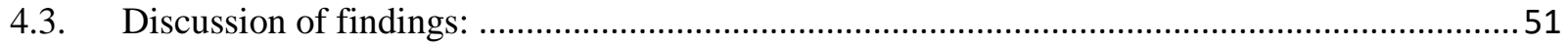

5 Conclusion:

5.1. Research findings and Implications \& Recommendations: ..................................................55

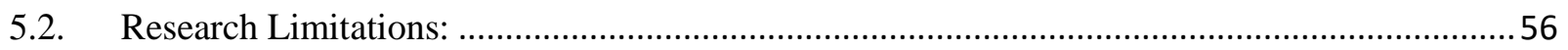

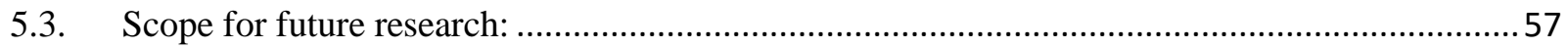

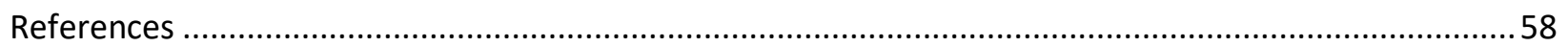

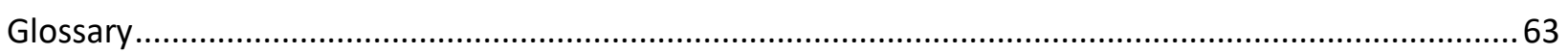




\section{List of Tables}

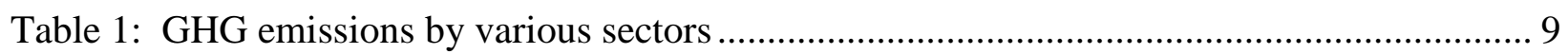

Table 2: Examples of some research on environmental disclosures and firm performances ....... 25

Table 3: Climate change issues for content analysis ................................................................. 31

Table 4: CCBE's Board Shareholder Confidence Index (BSCI) conversion mechanism ............. 35

Table 5: Climate change related to total disclosures by Oil \& Gas companies ............................. 40

Table 6: Climate change-related disclosures by categories by Oil \& Gas companies.................... 40

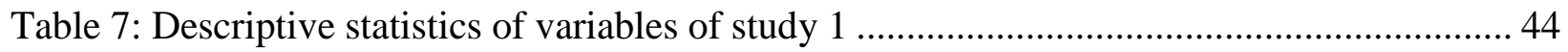

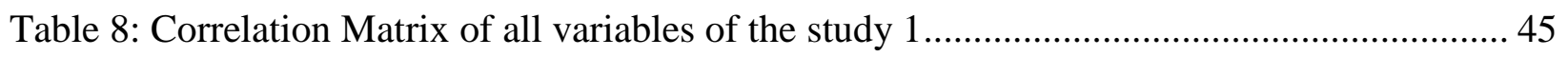

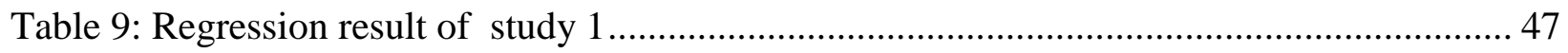

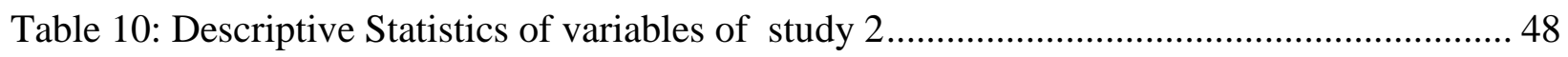

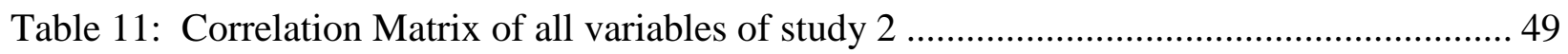

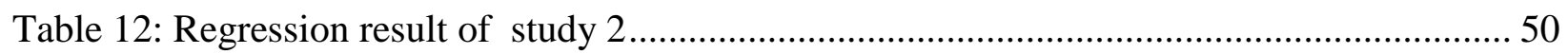




\section{List of Figures}

Figure 1: Theoretical Framework of the Research .............................................................. 23

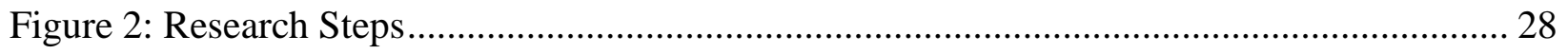

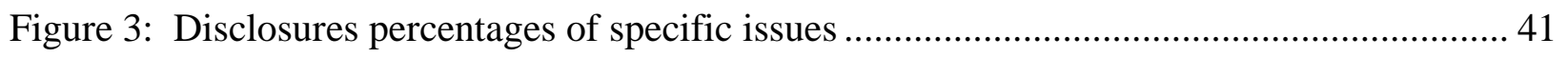




\section{Introduction}

Global warming and climate change gained importance during the last several decades. These have become a matter of great concern to all the stakeholders in society, including the government, customers, analysts, and institutional investors. Green House Gases (GHG) emission is the main reason for environmental degradation and climate change (Schultz \& Williamson, 2005). Other contributing factors include waste disposal and energy usage. The three most significant and unprecedented changes that are caused by the climate change are: ocean and atmosphere warming, rising of sea level, and diminishing snow and ice over the years (IPCC, 2014).

This critical issue of climate change enticed the attention of global leaders. The Kyoto Protocol, which was established in 2005 as the international treaty on climate change, requires that the members reduce the GHG emission up to a certain level. In 2015, the Paris agreement was signed by 195 countries and ratified by 185 countries (including Canada). As part of the emission reduction plan of Paris Agreement, Canada submitted a plan of a clean growth economy, under which it will try to reduce net emission by $80 \%$ in 2050 from the 2005 levels (Canada E.A., 2016).

Business organizations are the major GHG emitters. Therefore, the business communities are now facing pressure from global leaders, legislators, and other stakeholders to reduce GHG emission. Business organizations have a responsibility to alleviate the effect of climate change because they cause more emission of GHG (Downie \& Stubbs, 2013). Manufacturing industries are largely responsible for high energy consumptions in the industrial sector. As a result, they should take measures to enhance energy efficiency in manufacturing to reduce energy consumption and energy-related $\mathrm{CO}_{2}$ emissions (Biel \& Glock, 2016). Moreover, they should 
also confirm their accountability by disclosing information about their initiatives in corporate reports. Disclosure on climate changes is a serious issue to maintain the company's legitimacy in the eyes of the society. One of the critical means of increasing transparency is to disclose corporate strategies and actions on climate change to its stakeholders (Freedman \& Jaggi, 2011).

There is a considerable variation among the industries in terms of emissions of GHG. Agriculture, electricity, oil and gas are the major sectors that emit GHG in Canada. This study focuses on climate change disclosures issues of the oil and gas sector since it is the largest emitters of GHG in Canada. The oil and gas sector emitted GHG, which was almost equivalent of 189.5 megatons of carbon dioxide in the year 2017(Climate Change Canada, 2017).

\subsection{Research questions and research objectives:}

During the last few decades, several researchers investigated the climate change disclosures by the corporations. A number of studies attempt to reveal the determinants of climate change disclosures (Freedman \& Jaggi, 2005; Stanny \& Ely, 2008; Ben-Amar \& McIlkenny, 2015) and value relevance of climate change disclosures (Cormier, Ledoux \& Magnan, 2011; Clarkson, Fang, Li \& Richardson, 2013; Cho, Michelon, Patten \& Roberts, 2015). A review of the literature suggests that although there are many studies on the disclosures of climate changes issues, there is a lack of research that explores corporations' climate change disclosures in the oil and gas sector. Prior literature also highlights that no research to date has documented the determinants of climate change disclosures and value relevance of disclosures by the oil and gas companies in Canada. Based on this gap in the literature, this study investigates two fundamental research questions:

1. Are the oil and gas companies with the effective board of directors more likely to disclose their initiatives about climate changes? 
2. Does the extent of disclosures on climate change of oil and gas companies affect their market value?

This research investigates the extent of disclosure on the climate change issues in the publicly available documents, such as annual reports, annual information forms, and sustainability reports of the oil and gas companies listed in the TSX. The following specific objectives have been proposed:

1. To identify the current extent of disclosure on the climate change issues by the oil and gas companies.

2. To investigate the relationship between the disclosure of climate change issues and the boards' effectiveness for the oil \& gas companies.

3. To find out value relevance of climate change disclosures such as whether climate change disclosure can influence the firms' value.

\subsection{Overview of the research stages:}

This study developed an index related to the Disclosure of Climate Change Issues (DCCI). There are 80 oil and gas companies listed on the TSX. A total of 80 annual reports, 17 sustainability reports, and 80 Annual Information Form (AIF) of 2017 have been analyzed for the study. However, out of 80 companies, COMPUSTAT data are available for 58 companies. These 58 companies are considered to make a content analysis.

Regression analyses are done to find out the second and third objectives. This research includes a longitudinal study to find the relationship between boards' effectiveness and climate change disclosures. Board effectiveness is measured by the Board Shareholders' Confidence Index ${ }^{1}$

\footnotetext{
${ }^{1}$ Clarkson Centre for Business Ethics (CCBE) of Rothman School of University of Toronto developed and measured the Board Shareholders' Confidence Index (BSCI) in regards to Board of Directors' independence, board structure and board output. It annually publishes the BSCI rating from 2003 for the firms which are listed on the S\& P or TSX composite index.
} 
(BSCI) for this study. However, BSCI data are available for 22 companies from the year 2015 to 2017. Therefore, to make a longitudinal study, those 22 companies are considered. A multiple regression analysis was used to investigate the relationship between DCCI and BSCI. After finding the determinants, the study tries to find the value relevance of climate change disclosures. Disclosure index score developed from the content analysis of 58 companies is considered as an independent variable. The market to book assets ratio is used as a proxy of firm value. The market to book equity is also used to check the robustness' of the findings. From the literature of environmental disclosures, it is evident that firm size, profitability, and leverage affect climate-change disclosures (Freedman \& Jaggi, 2005; Stanny \& Ely, 2008). Previous climate change accounting research also showed that cross-listing effect influenced the disclosures level (Luo, Lan, \& Tang, 2012; Ben-Amar \& McIlkenny, 2015). Following the previous research studies, this study controls the effect of size, profitability, leverage, and crosslisting.

\subsection{Contributions of the study:}

The study offers the following three contributions:

1. The study explores the climate change disclosures of the oil and gas companies listed in TSX which have never been sufficiently investigated. The content analysis conducted by this study provides a summary of the Canadian oil and gas companies' reporting practices of climate change-related disclosures; hence, it closes the gaps in the environmental accounting literature. The findings conclude that climate change reporting by oil and gas companies in Canada is still at a low level. One possible reason for poor disclosures may be the absence of accounting standards for accounting for GHG emission for Canadian companies. It is hoped that the study will encourage the oil and gas companies to increase the extent of their climate change-related 
disclosure practices. The increased disclosures would also conform to stakeholders' expectations about corporate accountability to climate change.

Recently, the Canadian Securities Administrators (CSA) announced a project to review the climate-change disclosures (CSA, 2018). A major objective of the project is to assess whether the current security legalization and guidance are sufficient for the issuer to determine the climate change-related disclosures. The outcome of this analysis will help Canadian Securities Administrator to have insight into climate change disclosures practices and will provide a frame of references for developing related disclosures requirement.

2. This study investigates the relationship between the DCCI and the BSCI index for Canadian oil \& gas companies. It contributes to environmental accounting research because it investigates the relationship between climate change disclosures and corporate governance. The high and positive association between board effectiveness and climate change disclosures supports agency theory. It shows that effective boards play an important role in monitoring managerial actions, which in turn reduce agency problems and improve the climate change disclosures.

From a practical point of view, it is imperative to enhance board effectiveness of the oil and gas companies in Canada. The result supports the idea that only a few companies, which have efficient boards, will have very good disclosures on emission. Companies with a less effective board would be less likely to disclose their initiatives about climate change.

3. This research also explores the relationship between climate change disclosures and firm value. This research contributes to the literature concerning the empirical evidence of disclosures on climate change issues on the firms' value. The empirical evidence indicates that the extent of 
disclosures on climate changes do matter to the investors regarding the high market value of the firms. Findings should encourage Canadian oil and gas companies to reduce GHG emissions and to disclose their strategies and initiatives to GHG emissions reduction. 


\section{Literature Review}

The literature review section consists of seven primary sections. Section 2.1 provides a brief primer on climate change as major environmental concerns. Section 2.2 provides business sectors' contributions to GHG emission. Section 2.3 provides climate change regulation in Canada. Section 2.4 gives an overview of Canadian and international climate change-related disclosures framework. Section 2.5 discusses climate change disclosure literature and gaps in the literature. Section 2.6 discusses theoretical frameworks of the study and finally, section 2.7 discusses the development of hypotheses for the study.

\subsection{Climate change as a crucial environmental issue:}

Global warming and climate change issues have become critical topics of discussion for the last several decades. GHG emission is the main reason for environmental degradation and climate changes (Schultz \& Williamson, 2005). However, other factors also contribute to the climate change issues such as waste disposal and energy usage. IPCC (2014) identified three significant, unprecedented changes because of climate change since the 1950s. They are:

i. Ocean and atmosphere warming

ii. Rising sea level

iii. Diminishing snow and ice over the years.

Bebbington and Larrinaga-Gonzalez (2008) have identified four major impacts of GHG emission; those are: the early arrival of spring, increase in adverse weather events like storms, hurricanes, change in the rainfall levels, and a significant rise in the sea levels. IPCC predicts storms such as hurricanes, typhoons, and cyclones would frequently occur with great intensity (IPCC, 2014). 
Due to such severe negative environmental impacts, the world leaders, business communities and other stakeholders are concerned with climate change issues. The international treaty on climate change The Kyoto Protocol was entered in force in the year 2005, which required member countries to reduce GHG emission up to a certain level. Later in 2015, the Paris agreement was signed by 195 countries, and 185 countries, including Canada, ratified it. In the Paris agreement, all the signatory countries set a temperature goal, which is to reduce the emission below $2^{\circ} \mathrm{C}$ (UNCC, 2014). It proposed some legal obligations of the signatory countries like national climate plan for every five years, provide national emission inventory, and reports the achievement at least for every two years.

\subsection{The business sector as GHG emitter:}

The business sector is one of the major contributors to emissions of GHG because of its core functions such as electricity consumption, manufacturing process, distribution of goods and services. The business sector, particularly manufacturing business largely originates the energy consumptions. The huge consumption of energy is one of the major reasons for GHG emissions. Business should take measures to enhance energy efficiency in manufacturing to reduce energyrelated $\mathrm{CO}_{2}$ emissions (Biel \& Glock, 2016).

Although a business is responsible for the GHG emission, it is also severely affected by it. Its profitability and even long-run sustainability will also be affected by climate change. There are different risks of climate change that will affect the profitability and sustainability of the business. There are three broad categories of risk that climate change poses on businesses; they are physical, regulatory and business (Labatt \& White, 2007). Physical risk resulted from extreme weather events such as rising sea level, water shortages, and infrastructural damages. Regulator risk is related to the operations of the business because of carbon emission from direct 
as well as indirect emission such as carbon tax. Other business risks included the change in customer attitude and damage reputation (Haque, 2011).

There is a considerable variation among the industries in terms of emissions of GHG. Electricity and heat production (25\%), industry (21\%), agriculture, forestry and other use (24\%), and transportation (14\%) are the major emitters of GHG (IPCC, 2014). The oil and gas sector is the largest emitter of the GHG, which was almost the equivalent of 189.5 megatons of carbon dioxide in the year 2017(Climate Change Canada, 2017). Table 1 shows greenhouse gas emission data.

Table 1: GHG emissions by various sectors

\begin{tabular}{|l|l|}
\hline Sector & $\begin{array}{l}\text { GHG emissions } \\
\text { (megatons of carbon dioxide } \\
\text { equivalent) }\end{array}$ \\
\hline Oil and Gas & 189.5 \\
\hline Transportation & 173 \\
\hline Building & 85.6 \\
\hline Electricity & 78.7 \\
\hline Heavy Industry & 74.6 \\
\hline Agriculture & 72.8 \\
\hline Waste and others & 47.6 \\
\hline
\end{tabular}

Source: Climate Change Canada (2017)

\subsection{Climate change regulation in Canada:}

Canada is one of the major emitters of GHG. In a recent report on climate change performance showed that Canada is the third largest carbon emitter in the world and its performance is unsatisfactory in terms of the current level as well as the 2030 target (Burck, Marten, Bals, \& Höhne, 2018). 
During 2016, Canada, along with 195 countries, signed the Paris Agreement. Countries ratified the agreement commit to preventing global temperatures from rising more than $2^{\circ}$ Celsius above pre-industrial levels and to pursuing efforts to limit this rise to no more than $1.5^{\circ}$ Celsius. Following the Paris Agreement and its ratification, Canada submitted a plan of a clean growth economy, under which it targeted to reduce net emission by $80 \%$ in 2050 from the 2005 levels (Canada E.A 2016).

The Canadian government is taking action plan to a clean climate change policy. Federal Government is implementing a coordinated nation-wide carbon price. For many years, Canada had not a strong regulatory approach to climate policy (Eberlein \& Matten, 2009). In the early 1990's, Canada relied mainly on non- compulsory and voluntary approach to address the climate change issues (Jaccard, Rivers, \& Peters, 2009). However, this approach was unlikely to achieve government reduction of carbon emission target. As a result, Canada is now shifting from a voluntary approach to a strong regulatory measure to address climate change issues. Moreover, business leaders are also in favor of a strong regulatory measure of climate change. There is a major shift in the business leader to favor the climate change actions particularly after the year 2005 (Eberlein \& Matten, 2009). They are in favor of a strong regulation in federal climate policy instead of resisting the regulatory carbon constraint. In summary, Canada is now shifting towards a strong measure of climate change regulations.

\subsection{Climate change-related disclosures framework:}

\subsubsection{International climate change-related disclosures framework:}

There are many climate change-related reporting frameworks issued by various NGOs and other international organizations. Major global initiatives and forum who issue guidelines and framework about climate change issues are: Climate Disclosure Standards Board (CDSB), Carbon Disclosure Project (CDP), the UN and Coalition for Environmentally Responsible 
Economies (CERES), the World Business Council for Sustainable Development and World Resource Institute's Greenhouse Gas Protocol, and Global Reporting Initiatives (GRI).

The World Resource Institute (WRI), along with the World Business Council for Sustainable Development, first established GHG protocol standard in the year 1997. Global Reporting Initiative (GRI) requires the firms to disclose the information on GHG emissions according to the requirements of the GHG Protocol Corporate Standard (GRI, 2016). Carbon Disclosure Project (CDP) is another nonprofit project which requires that the firms voluntarily disclose significant information about their climate change activities (Kolk, Levy, \& Pinkse 2008). However, most of the voluntary GHG programs require both direct emission and indirect emission. GHG disclosures requirements of the GHG Protocol Corporate Standard will usually be compatible with most requirements. International Petroleum Industry Environmental Conservation Association (IPIECA) is the only global association which issued guidelines for the oil and gas industry. They issued disclosure frameworks for the oil and gas industry on the voluntary sustainability reporting.

\subsubsection{Climate change reporting framework in Canada:}

Canadian Security Administrator (CSA) issued environmental reporting guidelines for listed companies of TSX. The main regulation of environmental and social disclosure is National Instrument (NI) 51-102, Continuous Disclosure Obligations. Companies have to disclose all material information in the Management Discussion and Analysis (MD\&A) report and also in the Annual Information Form (CSA 2010). There are guidelines for companies to disclose environmental information like material information, environmental risk and related matters, risk oversight, and management. Schneider, Michelon \& Paananen (2018) presented current mandatory reporting on environmental and social matters in Canada, USA, and EU. They mentioned that environmental reporting rules in Canada require the material information on time. 
However, there has been room for discretion; for example: what is material, who the stakeholders are, how environmental and social liabilities are valued (i.e., discount rates) and what channels these items should be reported through (i.e., annual report versus sustainability report (Schneider et al., 2018). Recently, the CSA announced a project to review the disclosure by reporting issuers of risks and financial impacts associated with climate change. A major objective of the project is to assess whether the current security legalization and guidance are sufficient for the issuer to determine the climate change- related disclosures (CSA, 2018). It is expected that Canada is going to have a strong regulatory requirement of climate change- related disclosures for the corporations. However, there are problems of enforcement of climate change reporting. Schneider et al. (2018) mentioned that there is a good existing guidance on climate change disclosure; it is a matter of making it mandatory and enforcing it via the securities regulators. There may be a problem translating the existing guidance into disclosure.

Despite not having a strong regulatory supports, corporations still make the company report on climate-change activities. Wittneben and Kiyar (2009) identified political pressure as one major reason to report the climate change issues by the companies in Canada. Business communities are now facing pressure from global leaders, legislators, and other stakeholders to lessen GHG emission. The business organizations should fulfill their responsibilities by taking actions on climate change issues. On top of that, they should confirm their accountability by disclosing information about their initiatives in the corporate reports.

\subsection{Prior research on climate change-related disclosures}

There are vast numbers of research studies on climate change-related disclosures. Those studies can be grouped into two major streams.

1) Studies focused on the level of disclosures by the companies.

2) Studies are related to the determinants of the climate change-related disclosures. 


\subsubsection{Research on climate change- related disclosures levels (Stream 1)}

Many researchers tried to find the disclosures level by the companies. Freedman and Jaggi (2005) made a study on 120 GHG-emitting companies. They found that larger firms and firms in Kyoto-ratifying countries have higher disclosures levels. Stanny and Ely (2008) made a study on S\&P 500 companies' climate change-related disclosures. Their study also revealed that disclosures were higher only in larger firms. In another study, Freedman and Jaggi (2011) made a comparative analysis among firms from US, EU, Japan, Canada, and India. Their significant findings were that the companies within countries that ratified the Kyoto Protocol agreement, i.e., EU, Canada, and Japan, had better disclosure practices than companies from US and India, which had not signed the protocol or set limits on reducing pollution emission. Kolk, Levy, and Pinkse (2008) investigated the company's responses to climate change concerning carbon disclosure for FT500 companies. They found increasing response rates in terms of numbers of disclosing firms but the current level of disclosures is not satisfactory. Bebbington, Schneider, Stevenson, and Fox (2019) investigated fossil fuel reserves and resources disclosures and how they might change in response to global climate change agreements. One of their conclusions was that there is a relative absence of disclosures of unburnable carbon.

In summary, most of the studies, focused on the level of disclosures, concluded that climate change disclosures are still not at a satisfactory level.

\subsubsection{Research on the determinants of climate change disclosures (Stream 2):}

There are many studies which have tried to find the determinants of climate change reporting. Stanny and Ely (2008) identified the factors affecting the US S\&P 500 firms to take decisions for reporting on the effects of climate change. Findings revealed that corporate disclosure on climate change to institutional investors depended upon factors like size, previous disclosure, and foreign sales. Prado-Lorenzo, Rodriguez-Dominguez, Gallego-Alvarez, \& Garcia-Sanchez, (2009) 
investigated the determinants of corporate disclosure on GHG emissions and climate change on the 101 companies from the USA, Australia, Canada, and the European Union. They found that the corporate size and market capitalization are directly related to disclosure level and profitability (ROE) is inversely related. From the literature, it is evident that firm sizes, profitability, and leverage are the significant determinants of climate change disclosure.

There are several studies focused on the relationship between corporate governance and sustainability disclosures, but very few of them concentrated only on climate change disclosures. Haque and Deegan (2010) made a study of five major companies in Australia over the span of 16 years. They tried to find the relationship between various policies and procedures associated with climate change and respective companies' annual reports and sustainability reports disclosures. Findings revealed that, in many cases, the disclosures could not provide enough insight into climate change-related risks and opportunities, but the level of disclosure increased over the years. Ben-Amar and McIlkenny (2015) surveyed 200 firms in Canada from the year 2008 to 2011. They measure the quality of climate change disclosures using the annual CDP questionnaire. A significant association between the board's effectiveness and quality of carbon disclosures was discovered. In summary, it is found in the literature that corporate governance variable is one of the significant drivers of climate change disclosures.

\subsubsection{Research finding the relationship between climate change disclosures and firm values:}

There are several studies that tried to find the relationship between firm values and environmental disclosures. Plumlee, Brown, Hayes, and Marshall (2015) investigated the relationship between the quality of a firm's voluntary environmental disclosures and firm value. They studied for oil \& gas, chemical, food/beverage, pharmaceutical and electric utilities firms over the 2000-2005 periods and found that disclosure quality is positively associated with firm 
value. Cormier and Gordon (2001) studied a total of 212 Canadian companies annual reports from the year 1986 to 1993, and their result showed that there is a direct relationship between environmental information disclosed in a firm's annual report and its stock market value. In another study, Cormier and Magnan (2007) attempted to find the relationship between environmental reporting and firm performance, focusing on firms from Canada, France, and Germany. Their findings discovered that environmental reporting has a moderating effect on the firm performance in Germany, but it does not significantly impact the firm performances of Canadian and French companies. Cho, Michelon, Patten, and Roberts (2015) tried to find the potential legitimacy factors of Fortune 500 data from 1970 to 2010. Their result indicates that investors do not positively value CSR disclosures.

Many studies tried to find the association between voluntary disclosures and firm value in the market. Clarkson, Fang, Li, and Richardson (2013) examined the relationship between voluntary disclosures in firms' sustainability reports or equivalent web disclosures, and the enterprise value and cost of capital. Their study covered a sample of 195 firm-year observations, 92 firms from 2003, and 103 firms from the year 2006. Results showed that there is a significant positive relationship between firm valuation and environmental disclosure measure, but a firm's cost of capital is unrelated to the level of its voluntary environmental disclosure. Cho, Guidry, Hageman, and Patten (2012) tried to find out the association between environmental performance scores and voluntary disclosure practices of large US firms. They used a sample of 92 US firms who were facing a higher level of environmental exposure. They found a negative relation between environmental performance and disclosures, which suggests that worse performing companies make extensive disclosures. 
In summary, research on the relationship between environmental disclosures and firm value indicates a mixed result. One group of researchers found a positive relationship between environmental disclosures and firms' market-based performance (Cormier \& Magnan, 2001; Clarkson et al., 2013; Plumlee et al., 2015). On the other hand, another group of studies found a negative relationship between environmental disclosures and the firm's value (Cormier \& Magnan, 2007; Cho et al., 2012; Cho et al., 2015). However, most of the studies tried to find the association between environment reporting and firm value. There is still a considerable gap to precisely find the association between the climate change reporting and the firm value.

\subsubsection{Prior research on climate change-related disclosures of Canada}

Research on voluntary climate change-related disclosures of Canadian companies is still minimal. Most of the studies are limited to focusing on broad environmental disclosures rather than explicitly addressing climate change disclosures. As mentioned earlier, Freedman and Jaggi (2011) made a comparative analysis among US, EU, Japanese, Canadian and Indian companies and found Canadian companies along with EU companies have better disclosures than US and Indian Companies. Chelli, Durocher, and Fortin (2018) made a study on French and Canadian companies. Their study revealed that the French political system is more successful than that of Canada in initiating environmental reporting. Bebbington et al. (2019) reviewed the reporting requirements for fossil fuel companies, as well as a review of disclosure practices over time and across countries. They investigated 35 companies from Australia, Canada, China, Russia, South Africa, UK, and USA for the years 2011 and 2014. Of the 35 companies, 19 were for mining, 15 were oil and/or gas and one was a combined oil, gas and coal company. They concluded that there is a relative absence of disclosures on unburnable carbon. They also concluded that the mechanisms for identifying unburnable carbon (if it exists) are present in the existing regulatory 
environment and that there is no need to develop new guidance. What this finding suggests, however, is that there may be a problem translating the existing guidance into disclosure.

Ben-Amar and McIlkenny (2015) made a longitudinal study of 200 firms in Canada from the year 2008 to 2011. They used the annual questionnaire survey of CDP to measure the quality of climate change disclosures and found a significant association between the board's effectiveness and quality of carbon disclosures. Berthelot and Robert (2011) made a study on the disclosure of climate changes on Canadian oil and gas companies. Using the Canadian Institute of Chartered Accountant guidelines concerning climate change disclosures in annual reports, they tried to find the determinants of climate change disclosures. Findings revealed that disclosures of oil and gas companies are very low. High disclosures depend on the presence of environment committee, significant political exposure and strong media visibility, and a widely held ownership structure. This is potentially the only study that exclusively discusses about the Canadian oil and gas companies. However, their study focused only on the presence of environmental committee as corporate governance variable. In summary, most of the studies based on Canadian companies' climate change-related disclosures showed that disclosures are still at a mediocre level.

\subsubsection{Research Gap:}

Based on the literature on climate change disclosures, this study identified the following research gaps:

1. A review of the prior literature signifies that although there are many studies on the disclosures of climate changes issues, still there is lack of research investigating the association between corporate climate change disclosures and board of director's' effectiveness. Although there are few studies about Canadian companies, most of them focus on the GHG emission across the industries rather than any particular emission-intensive industry such as oil and gas. For example, Ben-Amar and McIlkenny (2015) tried to find an association between board 
effectiveness and climate change disclosures practices. Their study was based on CDP data and across the industries rather than focusing on the particular specific emission-intensive sector. There is a complete absence of studies related to finding an association between board effectiveness and climate change disclosures in the oil and gas sector.

2. A review of literature also highlights that no research to date has documented the determinants of climate change disclosures and value relevance of disclosures by the oil and gas companies in Canada. Some studies that tried to find the determinants of climate change disclosures in Canada (Berthelot \& Robert 2011; Ben-Amar \& McIlkenny, 2015) and firm value of climate change disclosures (Cormier et al. 2001; Cormier \& Magnan, 2007). However, none of them make both determinants and value relevance study.

3. Canada is one of the largest producers of GHG (Burck, Bals and Frisch 2018) and oil and gas companies are significant contributors to the GHG emission. No longitudinal study investigates Canadian oil and gas companies' disclosure practices within their corporate governance context.

Based on the above-identified research gap, this study answers the following questions.

1. Are the oil and gas companies with the effective board of directors more likely to disclose their initiatives about climate changes?

2. Does the extent of disclosures on climate change of oil and gas companies affect their market value?

\subsection{Theoretical Framework}

This section summarizes the most widely used theoretical frameworks in prior literature in voluntary disclosure area, which are agency theory, legitimacy theory, and stakeholder theory.

\subsubsection{Agency Theory:}

One of the widely used theories in environmental accounting research is agency theory. Agency theory tells that because of the principal-agent relationship in the organization, problems arise 
particularly in case of information asymmetry when an agent might work for his/her best interest rather than for the principal. However, there are two opposite views of agency theory in applying environmental disclosures. In applying the agency theory to interpret the motivation of CSR, Friedman argued that corporate officers and labor leaders would invest more on CSR to build their reputation at the cost of the stockholders (Freidman, 2002). Additionally, there is an opposite view. The principal may voluntarily disclose on CSR so that it can increase the information transparency and reduce the investment risks. The "agency" cost associated with political and legislative actions were also decreased (Benston, 1982; Ness \& Mirza, 1991).

This research examines the relationship between board effectiveness and climate change disclosures. One of the fundamental hypotheses of this research is that the extent of board effectiveness has a positive effect on climate change disclosure. Agency theory assumes that because of separation from management and ownership, the board serves a monitoring role over management on behalf of shareholders (Jensen \& Meckling, 1976; Fama \& Jensen, 1983). Based on agency theory, much previous research on the voluntary disclosures revealed that corporate governance variables, like independent directors, non-executive directors, leadership structure, enhance the disclosure transparency (Chen \& Jaggi, 2000; Michelon \& Parbonetti, 2012).

Governance literature shows that effective boards play an important role in monitoring managerial actions, which in turn reduce agency problems and improve the information environment (Cheng \& Courtenay, 2006). Management does this to ensure the symmetrical information in the market. Considering the information asymmetry in the market between manager and stakeholders, voluntary disclosures on climate change information to the market may increase the information transparency, and associated agency cost will decrease. 


\subsubsection{Legitimacy Theory}

Organizations are using the resource of the society. They cannot create any problems towards society; otherwise, their existence will be at stake. For this reason, an organization will seek to ensure that it operates within the bounds and norms of society (Deegan, 2002). Legitimacy theory is a widely used theory in environmental accounting research (Prado-Lorenzo et al., 2009; Freedman \& Jaggi, 2011; Pellegrino \& Lodhia, 2012). There is a growing awareness among the stakeholders about environmental issues. Now they expect to know whether organizations are doing anything harmful to the environment. Reporting to stakeholders will fulfill their expectations towards corporations.

The concept of environmental legitimacy is widely used to explain the impact of environmental disclosures. Bansal and Clelland (2004, cited by Cormier \& Magnan, 2015) define environmental legitimacy as 'the generalized perception or assumption that a firm's corporate environmental performance is desirable, proper, or appropriate.' Environmental disclosures may allow the firms to manage the perception of its environmental performance (Cormier \& Magnan, 2015). Climate change is a significant aspect of an environmental issue. There are many stakeholders like regulators, media, the environmental group, the general public who are more concerned with the climate change activities of the business.

One of the major arguments of legitimacy theory is that companies use the disclosures as a tool of legitimation. Companies are facing political and social pressures from the stakeholders' group; as a result, they use disclosures as a tool to reduce the exposures (Deegan, 2002; Patten, 1991). One of the key arguments of CSR disclosures is that companies disclose to enhance their image rather than what they are actually doing (Gray, 2006; Paten, 2012). Cho et al. (2012) show that voluntary environmental reporting, encouraged by concerns of enhancing social legitimacy, 
actually serve as a potential impairment to future improvements in corporate environmental performance.

One of the hypotheses of this research is that board effectiveness has a positive effect on climate change disclosure. Top management is responsible for ensuring accountability to stakeholders. Management can do this by recognizing the legitimacy gap and carry out social practices and disclose accordingly to the stakeholders. Internal corporate governance (such as ownership and board composition) plays a vital role in reducing the legitimacy gap through CSR disclosures (Khan, Muttakin, \& Siddiqui, 2013). Effective board of directors, particularly in emission incentive industry like oil and gas, are likely to disclose climate change initiatives to reduce the legitimacy gap.

\subsubsection{Stakeholder Theory}

Over the years, the main goal of a business was to maximize the shareholders' wealth. Now it is not limited only to shareholders. Businesses have to deal with various stakeholders and their interests. They have to identify the effect of their activities on all stakeholders to ensure the sustainability of the business. Stakeholder theory is cited by many researchers in social and environmental accounting research. Various stakeholders now create pressure on the companies to report on climate change issues. In addition to the investors, other stakeholders such as legislators, consumer groups, environmentalists, governments, leaders, and trade associations also demand that information (Prado-Loranzo et al., 2009). To maintain the long run relationship with its stakeholders', companies should disclose the information on climate change issues according to their needs.

Benefits of climate change disclosures to the external stakeholders can be addressed through stakeholder's theory. Stakeholders are now more concerned with the firm's climate change 
initiatives. Various stakeholders now created pressure on firms to reduce the environmental impacts of their activities and to communicate their environmental performance (Radhouane, Nekhili, Nagati, \& Paché, 2018). Moreover, board effectiveness is crucial in satisfying the demand of different stakeholders groups (Hillman, Keim, \& Luce, 2001). Firms with more effective boards would disclose more climate change information to satisfy the stakeholders.

Researchers also used stakeholder theory to identify the value relevance of environmental disclosures. Shareholders are the major stakeholders and they are primarily concerned with the expected future profitability of the company (Cormier \& Magnan, 2015). Many previous researchers verified the positive association between voluntary disclosures of carbon emissions and firm value within the context of stakeholders' theory. Voluntary environmental reporting allows stakeholders to precisely estimate the future earnings. As a result, voluntary disclosures enhance the firms' stock market valuation (Cormier \& Magnan, 2007). The extent of nonfinancial information like Carbon emission disclosures provides investors use for valuation of firms (Matsumura et al., 2014). In summary, climate change reporting can contribute to the value of the firm by offering useful information to the stakeholders.

\subsubsection{A combination of the theoretical framework of this research}

Two things are common for all the theories mentioned above, which are

a) Providing information (through agent) because of information asymmetry.

b) Stakeholders' expectation and legitimacy to report them.

Business organizations have to meet their expectations of society. Otherwise, there will be a risk of expectation gap which will create the risk of survival of the organizations. Since there is information asymmetry of information, management should provide information to 
stakeholders. Stakeholders' expectation can be met through reporting. Otherwise, organizational legitimacy cannot be maintained. Therefore, the proposed study will be based on these prominent theories: Agency theory, legitimacy theory, and stakeholder theory.

\section{Figure 1: Theoretical Framework of the Research}

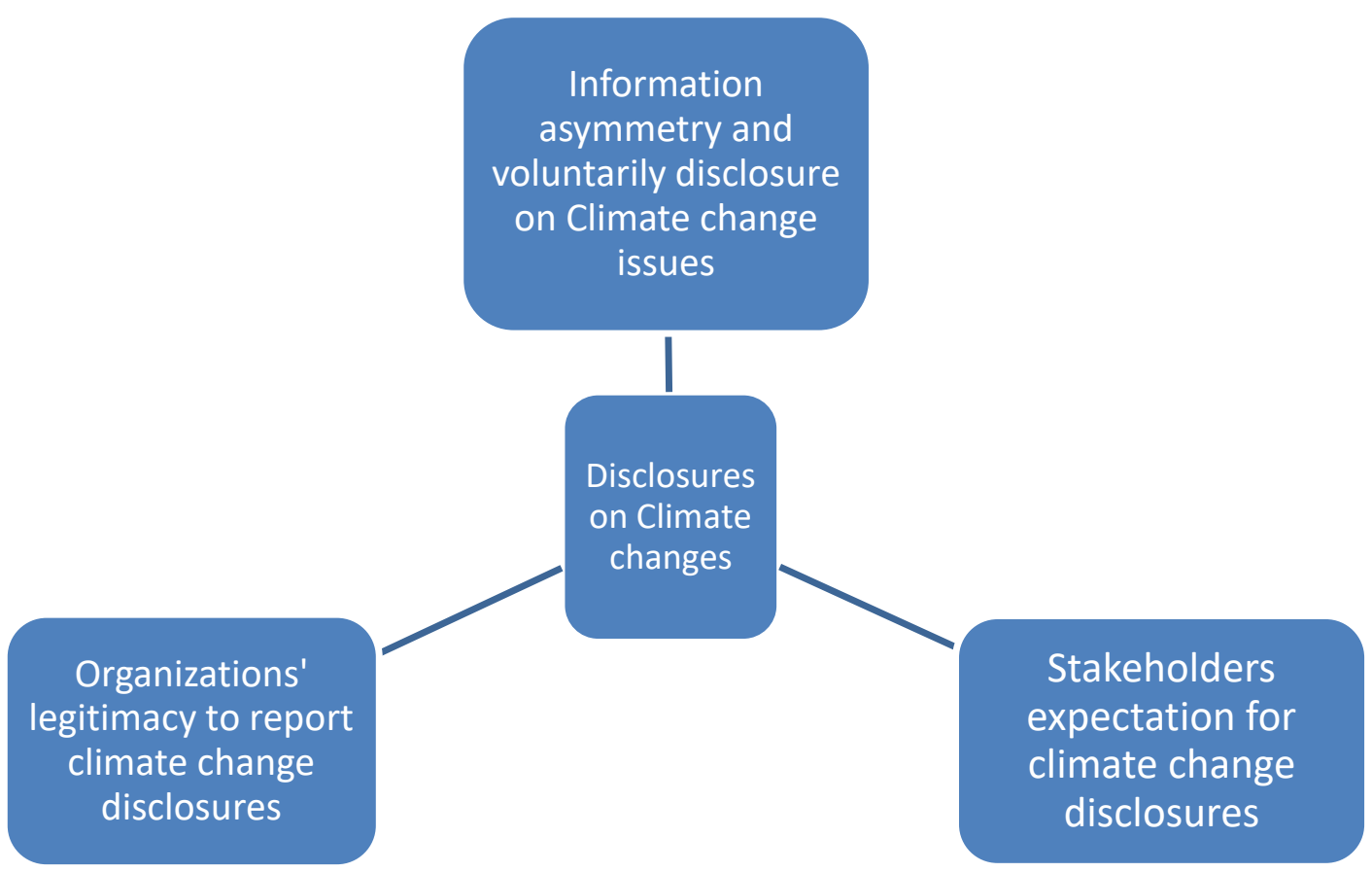

\subsection{Hypothesis development:}

\subsubsection{Board effectiveness and climate change disclosures:}

The primary objective of this research is to investigate the nature and extent of disclosure to which board effectiveness influence disclosures on climate change issues of oil and gas companies in Canada. Board effectiveness is measured differently in previous studies. One of the measures to use the board effectiveness in Canada is Board Shareholders' Confidence index (BSCI) data. In some previous literature, BSCI was used as the primary variable of interest. 
Switzer and Cao (2011) use BSCI to find the relationship between board independence and firm performance in Canada. Ben-Amar and McIlkenny (2015) also used the BSCI index to measure the relationship between board effectiveness and voluntary disclosures of CDP data.

Many previous studies on the voluntary disclosures relate corporate governance variables such as independent directors, non-executive directors, leadership structure, with the disclosure transparency (Chen \& Jaggi, 2000; Michelon \& Parbonetti, 2012).

Canada has a reputation as climate policy laggard, and its regulatory approach is not strong enough (Eberlein \& Matten, 2009). It is expected that the board of directors will report the stakeholders about climate change issues in the absence of strong regulatory guidance (BenAmar \& McIlkenny, 2015).

In this study, I argue that board effectiveness will increase the disclosures of oil and gas companies in Canada for three reasons. First, the agency theory suggests that the opportunistic managers have the incentive to maintain information asymmetry, particularly if disclosures of information have the potential to affect their reputation capital negatively. Governance literature shows that effective boards play an important role in monitoring managerial actions, which in turn reduce agency problems and improves the information environment (Cheng \& Courtenay, 2006). Thus based on the extant literature, I predict that board effectiveness, by way of reducing agency problem, will enhance disclosures on climate change issues. Second, board effectiveness is crucial in satisfying the demand of different stakeholders groups (Hillman, Keim, \& Luce, 2001).Given the increasing awareness of climate change issues around the world and demand for more information about the issues from different stakeholders groups, I predict that the effective board is likely to respond to this demand more actively. Accordingly, I expect firms with the more effective board to disclose more climate change information to satisfy the stakeholders. 
Finally, studies suggest that corporate board plays a vital role in ensuring organizational legitimacy through corporate disclosures (Khan, Muttakin, \& Siddiqui, 2013).Based on the legitimacy theory of corporate disclosures; I predict that effective board will disclose more climate change disclosures to gain legitimacy and support from society.

That is why this study hypothesizes:

$H_{1}$ : The extent of board effectiveness has a positive effect on climate change disclosure

\subsubsection{Climate change disclosures and firm value:}

Many previous studies explore the relationship between climate change disclosures and firm values. Those studies can be grouped into three types. Some of the examples of the literature that explores the relationship between environmental disclosures and firm values/performances are provided in Table 2 .

Table 2: Examples of some research on environmental disclosures and firm performances

\begin{tabular}{|l|l|l|}
\hline $\begin{array}{l}\text { Environmental disclosures } \\
\text { and Firm performances }\end{array}$ & Study & Nature of the relationship \\
\hline $\begin{array}{l}\text { Mandatory environmental } \\
\text { disclosures and Firm } \\
\text { performances }\end{array}$ & $\begin{array}{l}\text { Blacconiere and Patten, } \\
1994\end{array}$ & $\begin{array}{l}\text { Negative market reaction for } \\
\text { environmental disclosures }\end{array}$ \\
\cline { 2 - 3 } & Connors et al., 2013 & $\begin{array}{l}\text { Mixed (both positive and negative) } \\
\text { market reaction to environmental } \\
\text { disclosures }\end{array}$ \\
\hline $\begin{array}{l}\text { Voluntary Environmental } \\
\text { disclosures and firm } \\
\text { performances }\end{array}$ & $\begin{array}{l}\text { Matsumura et al., 2014; } \\
\text { Cho et al., 2015 }\end{array}$ & $\begin{array}{l}\text { Negative firm value for environmental } \\
\text { disclosures }\end{array}$ \\
\cline { 2 - 3 } & Plumlee et al., 2015 & $\begin{array}{l}\text { Voluntary environmental quality is } \\
\text { positively associated with firm value }\end{array}$ \\
\hline $\begin{array}{l}\text { Voluntary environmental } \\
\text { disclosures in sustainability } \\
\text { reports and firm } \\
\text { performances }\end{array}$ & Clarkson et al., 2013 & $\begin{array}{l}\text { Voluntary environmental disclosure } \\
\text { enhances firm value }\end{array}$ \\
\cline { 2 - 3 } & Qiu et al., 2016 & $\begin{array}{l}\text { No significant relationship between } \\
\text { environmental disclosures and firm } \\
\text { performances }\end{array}$ \\
\hline
\end{tabular}

The first group of studies tried to find the relationship between mandatory environmental disclosure and firms' market performance (Blacconiere \& Patten, 1994; Connors et al., 2013). 
The second group studied the relationship between voluntary environmental disclosures and firms' value (Matsumura et al., 2014; Plumlee et al., 2015). The third group of studies tried to establish the relationship between economic performance and voluntary disclosures of environmental information through annual report and sustainability reports (Clarkson et al., 2013; Qiu et al., 2016).

However, research on the relationship between environmental disclosures and firm value gives a mixed result. One group of researchers find a positive relationship between environmental disclosures and firms' market-based performance (Cormier \& Magnan, 2007; Clarkson et al. 2013; Plumlee et al. 2015). One of the major arguments for such a positive relationship stems from the fact that if firms take proactive environmental strategies, this may convey positive signals to the investors which in turn enhances firm value (Clarkson et al., 2013). On the other hand, another group finds a negative relationship between environmental disclosures and the firm's value (Cormier \& Magnan, 2007; Cho et al., 2015). One of the major explanations of the negative relationship is the moderating effect of firms' environmental performances. The companies with worse environmental performance tend to disclose more extensive environmental disclosures to reduce exposures arising from their environmental impacts (Cho et al., 2012; Cho et al., 2015).

The studies suggest that there may be either a positive or negative relationship between environmental disclosures and firm performance. In the context of this study, I argue that climate change disclosures may convey positive signals about the pro-active environmental strategies, which in turns reduce the risks (discount rate). Based on this argument, I predict that climate change disclosures would enhance firms' market-based performances. However, if the climate change disclosure is a mere reflection of worse environmental performance, shareholders will 
require additional risk premium, which in turn reduces firms' market-based performances. Thus given the competing argument, I, therefore posit the alternative hypothesis as:

$\mathrm{H}_{2}$ : Climate change reporting has an impact (either positive or negative) on the market performance of the firm. 


\section{Methodology}

\subsection{Research Steps:}

Figure 2: Research Steps

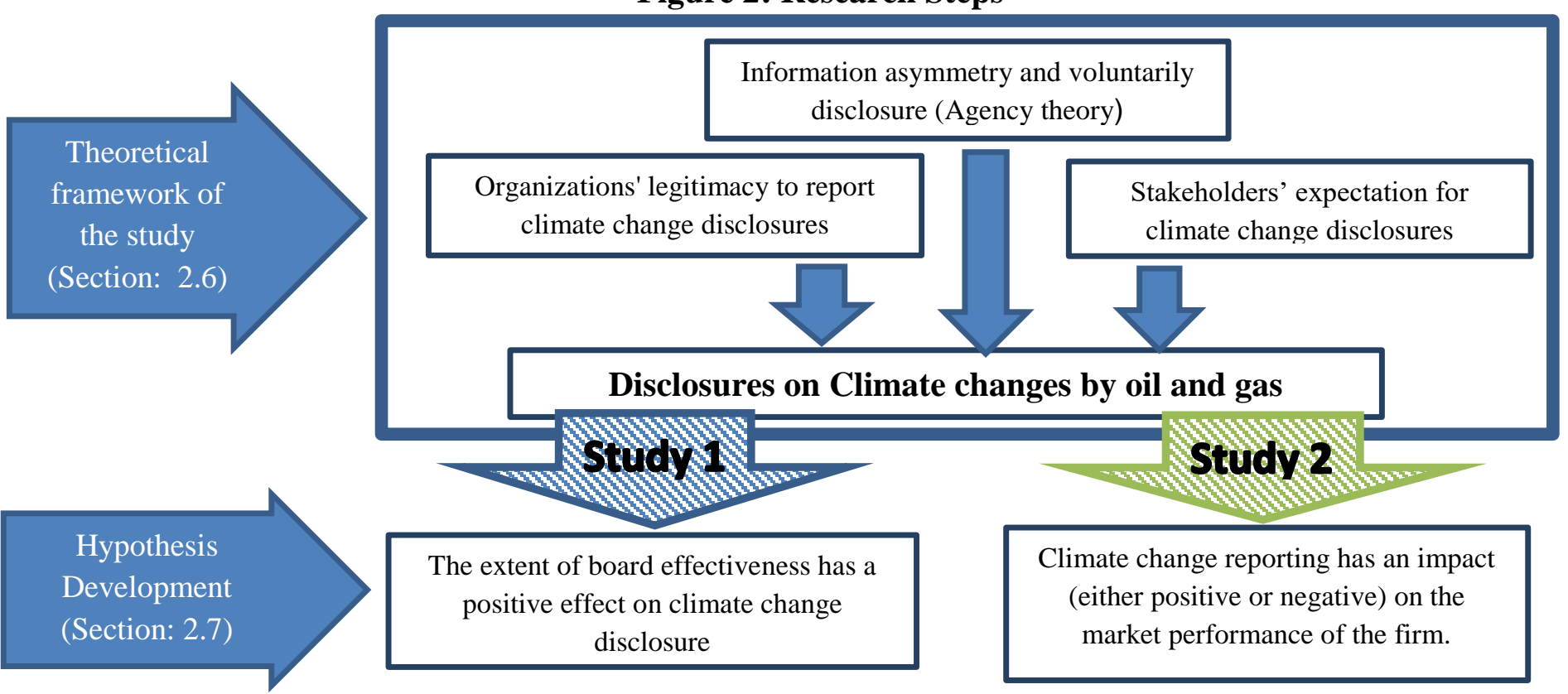

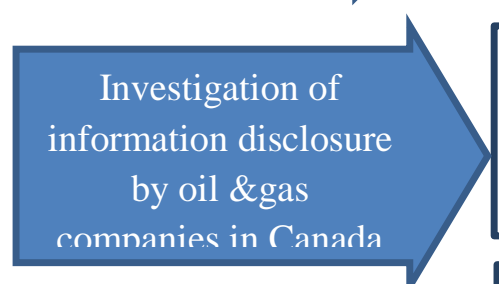

Development of

through content analysis (Section:3.3.1

Sample Selection and Data collection disclosure index (Section: 3.3.2)

Research Question 1: Are the companies with effective board of directors more likely to disclose climate changes initiatives?

\section{Model 1}

Dependent Variable: Disclosures on climate change issues (DCCI)

Independent Variable: Board

Effectiveness (Board Shareholder

Confidence Index score)

Control Variables: Size, Profitability,

Leverage, Cross listing, Sales_

growth

Equation 1:

$\mathrm{DCCI}_{\mathrm{i}}=$

$=\alpha+\beta_{1}\left(\mathrm{BSCI}_{\mathrm{i}}\right)+\beta_{2}\left(\mathrm{SIZE}_{\mathrm{i}}\right)+\beta_{3}($ Leverag

$\left.\mathrm{e}_{\mathrm{i}}\right)+\beta_{4}\left(\mathrm{ROA}_{\mathrm{i}}\right)+\beta_{5}($ Cross-

Sample: A total of 22 listed oil and gas companies in TSX from the year 2015 to 2017

Data collection: Sustainability reports, Annual Reports, Annual Information Forms, Compustat Database, University of Toronto's Clarkson Centre for Business Ethics for BSCI index

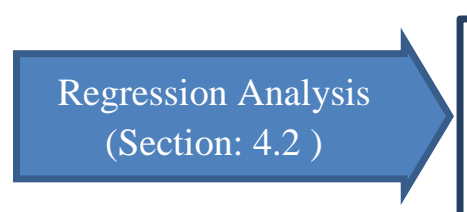

Study one: Board effectiveness and Climate change disclosures:

BSCI has a positive association with disclosures controlling all the other variables known to affect the disclosures (Table 6,7 and 8)

The high and positive association between board effectiveness and climate change disclosures supports the idea that only a few companies, which have efficient boards, will have very good disclosures on emission
Research Question 2: Does the extent of disclosures on climate change of oil and gas companies affect their market value?

\section{Model 2}

Dependent Variable: Firm Value Independent Variable: Disclosures on climate change issues (DCCI) Control Variables: Size,

Profitability, Leverage

Equation 2:

$\mathrm{FVi}=\alpha+\beta 1(\mathrm{DCCIi})+\beta 2(\mathrm{SIZEi})+$ $\beta 3($ LEVERAGEi) $+\beta 4($ ROAi) + $\beta 5(\mathrm{ROEi})+\varepsilon i$

Sample: A total of 58 oil and gas companies listed in TSX for the year 2017.

Data collection: Sustainability reports, Annual Reports, Annual Information Forms, Compustat Database

Study two: Climate Change disclosures and Firm Value:The result signifies that the firm's value positively reacts to the disclosures of climate change information by the sample companies (Table 9, 10 and 11)

The empirical evidence indicates that the extent of disclosures on climate changes do matter to the investors regarding the high market value of the firms. 
Figure 2 presents the major research steps. At the very first stage, I conduct a detailed literature review of the existing literature on climate change disclosures. Based on the review of the literature, I identified the research gaps which are explained in section 2.5.5. The theoretical framework of this study is explained in section 2.6. Agency theory, Stakeholders' theory, and Legitimacy theory, these three theories are formed as the basis of this research. Based on the theoretical frameworks, two hypotheses have been developed, which are explained in section 2.7. At the very first step of the research method, I conduct a content analysis on the publicly available documents of the oil and gas companies. I develop disclosures on climatic change issues (DCCI) based on the content analysis. Sample selection and data collection have been done on the second stage and are explained in section 3.3.2. On next stage (in section 4.2) regression analyses have been done to test the hypotheses. At last step, (in section 4.3) details analysis has been done, outline the contribution of the research and conclude with some limitations and recommendations.

\subsection{Research Objective and Research questions:}

The major objective of this study is to investigate the climate change information by the oil \& gas companies in Canada. This research investigates the nature and extent of disclosure on the climate change issues in the publicly available documents such as annual reports, annual information forms, and sustainability reports of the oil and gas companies listed in the TSX.

This study comes with the following two research questions:

1. Are the oil and gas companies with the effective board of directors more likely to disclose their initiatives about climate changes?

2. Does the extent of disclosures on climate change of oil and gas companies affect their market value? 


\subsection{Methodology of the study}

To find the answer to two specific research questions, research methods are designed in three stages (Figure 2).

\subsubsection{Stage One: Development of the Disclosure Index:}

At the very first stage, a disclosure index is developed through a content analysis of annual reports, annual information forms, and sustainability reports. According to Pellegrino and Lodhia (2012), content analysis can be considered as a commonly used research technique in the social and environmental reporting research that covers the issue of voluntary disclosure.

The index is developed from the research organizations and scholarly publications who give detailed guidelines about the disclosures of the climate change reporting by the companies. The following guidelines are considered to create the disclosure index for this study:

1. GRI guidelines \& GHG Protocol Corporate Standard

2. Oil and gas industry reporting guidelines (IPIECA)

3. Scholarly articles using disclosures index on climate change reporting

From the above source, climate change disclosure issues have been developed where 16 specific issues are covered under five general topics. The justification of the inclusion of each item in the disclosure index is that every disclosure item should be at least in more than one document. If two reports use the same disclosure related issue, then it can be said that the issue signifies the importance to be included in the disclosures index. Table 3 presents the 16 specific issues under the five general issues. 
Table 3: Climate change issues for content analysis

\begin{tabular}{|c|c|}
\hline General Issues & Specific Climate change-related disclosers \\
\hline $\begin{array}{lll}\text { a. } & \text { Board } & \text { oversight } \\
& \text { Management responsibility }\end{array}$ & $\begin{array}{l}\text { 1. The organization has a specific board committee to oversee the } \\
\text { environmental affairs } \\
\text { 2. The organization has a specific board committee on climate } \\
\text { change and GHG-related issues } \\
\text { 3. CEO/chairperson expresses the organization's views on the } \\
\text { issue of climate change through publicly available documents } \\
\text { such as annual reports, sustainability reports and websites. }\end{array}$ \\
\hline \multirow{10}{*}{ b. Emission Accounting } & 4. An organization report $\mathrm{GHG}$ in $\mathrm{CO}_{2}$ equivalent \\
\hline & $\begin{array}{l}\text { 5. Reporting of Scope } 1 \text { (direct) and Scope } 2 \text { (Indirect) } \mathrm{CO}_{2} \\
\text { emissions }\end{array}$ \\
\hline & $\begin{array}{l}\text { 6. Report total quantity of energy consumed in oil and gas } \\
\text { operations or other business activities. }\end{array}$ \\
\hline & 7. Report the quantity of hydrocarbon gas flared from operations. \\
\hline & $\begin{array}{l}\text { 8. Report total volume of freshwater withdrawn and Report total } \\
\text { volume of freshwater consumed. }\end{array}$ \\
\hline & 9. Total quantity, in metric tons, of hazardous waste, disposed. \\
\hline & $\begin{array}{l}\text { 10. A section in annual report/Annual Information Form devoted } \\
\text { to climate change or global warming }\end{array}$ \\
\hline & $\begin{array}{l}\text { 11. The organization has set an emission baseline year by which to } \\
\text { estimate future GHG emission trends. }\end{array}$ \\
\hline & 12. Methodologies used to calculate or measure emissions \\
\hline & $\begin{array}{l}\text { 13. The organization has third-party verification processes for } \\
\text { GHG emission data. }\end{array}$ \\
\hline c. Research and Development & $\begin{array}{l}\text { 14. The organization has the policy to develop alternative/ } \\
\text { renewable energy such as Nuclear, solar, hydropower and wind } \\
\text { energy }\end{array}$ \\
\hline d. Reporting Benchmark & $\begin{array}{l}\text { 15. The organization has the policy to comply with GRI guidelines } \\
\text { and/or GHG Protocol standard }\end{array}$ \\
\hline e. Potential Liability Reduction & $\begin{array}{l}\text { 16. The organization has a policy to minimize the potential } \\
\text { regulatory risk and physical threats to assets related to climate } \\
\text { change }\end{array}$ \\
\hline
\end{tabular}

Binary values are used to develop the index, i.e., 1 for the disclosure of a particular item and 0 for nondisclosure. This technique is common and accepted in much environmental accounting research (see: Prado-Lornzo et al., 2009; Haque \& Deegan, 2010). Both the weighted index and the un-weighted index are used in those studies. In this study, the un-weighted disclosure index was prepared. Prado-Lorenzo et al. (2009: 1142) mentioned that 'studies that use both weighted 
and un-weighted indices draw similar conclusions from both types of indices.' A total score for all these 16 items is considered. That means a company can get the highest score of 16 for disclosing all these items. The lowest score can be 0 in case of non-disclosure of all of these items.

Items included in the list imply the quality of disclosures. Many of the items are used from the GRI guidelines (such as: emission accounting and reporting benchmark items). According to Clarkson et al. (2008), poor environmental performers will not want to conform to GRI guidelines. Moreover, this content analysis includes some firm's disclosures of vision and environmental strategy claims (such as Board oversight \& Management responsibility, Research and Development, Potential Liability Reduction). These kinds of initiatives can represent true commitment to protecting the environment (Clerkson at el., 2008). Both types of disclosures implied the quality of disclosures. Despite using binary values, a higher score should mean higher quality since the items in the list would imply quality.

\subsubsection{Sample selection and data collection}

Out of eighty oil and gas companies listed in TSX, 17 companies published a sustainability report, and the rest did not. The annual reports, annual information forms, and sustainability reports for all companies included in the study were downloaded from company websites and SEDAR.

The answer to each research question is based on a separate study. The effect of board effectiveness on climate change disclosure is examined using a longitudinal study (Study 1). It allows finding the relationship between board effectiveness and climate change disclosure. BSCI (Board Shareholders' Confidence Index) is considered a primary variable of interest for Study 1. BSCI data are available for 22 oil \& gas companies listed in TSX. Those 22 companies 
are reviewed from the year 2015 to 2017 . Disclosures index, which is developed in stage one through content analysis, is a dependent variable of interest for Study 1. Control variables that were hypothesized to affect climate change disclosures include company size, profitability, and leverage. Those were obtained from the company annual reports \& COMPUSTAT.

Study 2 allows finding the relationship between climate change reporting and the market performance of the firm. For this study, a total of 80 annual reports, 17 sustainability reports, 80 Annual Information Form (AIF) of the listed oil and gas companies of TSX have been analyzed for the year 2017. However, out of 80 companies, COMPUSTAT data are available for 58 companies. These 58 companies are considered for studies to make content analysis for the year 2017. The disclosures index score of these 58 companies is the primary variable of interest for Study 2. Firm value is a dependent variable and is obtained from the COMPUSTAT database. Control variables that were hypothesized to affect the firm value were derived from the company annual reports \& COMPUSTAT. They include company size, profitability, and leverage.

\subsubsection{Stage Two: Regression Analyses}

After the data collection and identifying all the variables, two regression analyses have been conducted in the next stage to test the two hypotheses.

\section{Study 1: Association between board effectiveness and climate change disclosures}

The first study tries to find out the determinants of disclosures of climate changes issues. This study investigates the relationship between disclosure and board effectiveness to find the determinants. In this study, the primary independent variable is a corporate governance variable which is expressed as the board of director's effectiveness. Here the board of director's effectiveness is measured by the Board Shareholders' Confidence index (BSCI). Clarkson Centre 
for Business Ethics (CCBE) of Rothman School of University of Toronto developed and measured the Canadian Corporate governance best practice. They annually publish the BSCI rating from 2003 for the firms which are listed on the S\& P or TSX composite index.

CCBE measured the firms' board of directors' effectiveness ${ }^{2}$ in the following three dimensions.

1. Individual potential;

2. Group Potential; and

\section{Board Decision Output.}

1. Individual potential. It focuses on the directors and represents how they contribute to effective governance. It has three principal categories: Directors' Independence, Director Stock Ownership, and Director Meeting Attendance. Director's independence measures the potential influence of management \& other directors and boards. It is measured by the independence from management, directors' interlock and excessive board membership. Director stock ownership is measured by the directors' motivation to act in the best interest of shareholders. Director Meeting Attendance is measured by the percent of meetings attended by the directors.

2. Group Potential. It indicates the board's collective skill set and is measured through board structure (CEO/Chair split, committee independence, share structure), board evaluation process and, disclosures of board' skills.

3. Board Decision Output. It is measured through (i) compensation (decision that influences dilution, pay for performance and company loans), (ii) decision related to directors' election, and (iii) decision related to the CEO succession plan.

2 Detail description of BSCI methodology can be found to the CCBE website (http://www.rotman.utoronto.ca/FacultyAndResearch/ResearchCentres/ClarksonCentreforBoardEffectiveness/Board ShareholderConfidenceIndex). 
The overall score depends on individual potential, group potential, and past practices. It is calculated based on the scores assigned to the three dimensions listed above. The letter grades will be assigned to the ranges of the Overall score (Table 4).

Table 4: CCBE's Board Shareholder Confidence Index (BSCI) conversion mechanism

\begin{tabular}{|l|l|}
\hline Overall score & Grade \\
\hline 100 & AAA+ \\
\hline $95-99$ & AAA \\
\hline $88-94$ & AA \\
\hline $75-89$ & A \\
\hline $50-74$ & B \\
\hline$<50$ & C \\
\hline
\end{tabular}

BSCI is often used as the primary variable of interest. For example, Switzer and Cao (2011) use BSCI to find the relationship between board independence and firm performance in Canada. Ben \& McIlkenny (2015) also used the BSCI index to find the association between boards' effectiveness and voluntary disclosures of climate change information.

The study hypothesizes that:

$H_{1}$ : The extent of board effectiveness has a positive effect on the climate change disclosure The following equation is used as a regression model for Study 1:

$\operatorname{DCCI}_{\mathrm{i}}=\alpha+\beta_{1}\left(\mathrm{BSCI}_{\mathrm{i}}\right)+\beta_{2}\left(\mathrm{SIZE}_{\mathrm{i}}\right)+\beta_{3}\left(\right.$ Leverage $\left._{\mathrm{i}}\right)+\beta_{4}\left(\mathrm{ROA}_{\mathrm{i}}\right)+\beta_{5}\left(\right.$ Cross-listing $\left._{\mathrm{i}}\right)+\beta_{5}\left(\mathrm{Sal}_{-} \mathrm{G}_{\mathrm{i}}\right)+$ $\varepsilon_{\mathrm{i}}$

Here,

$\mathrm{DCCI}_{\mathrm{i}}=$ Disclosure Index on Climate Change issues for company $\mathrm{i}$.

$\mathrm{BSCI}_{\mathrm{i}}=$ Board Shareholders' Confidence Index for company i.

$\mathrm{SIZE}_{\mathrm{i}}=$ Total assets of company $\mathrm{i}$. This is a representation of company size.

LEVERAGE $\mathrm{i}_{\mathrm{i}}=$ Leverage of company i. It is found through the ratio of total debt to stockholders' equity.

$\mathrm{ROA}_{\mathrm{i}}=$ Return on Assets. It is measured by dividing the net income to the total assets of company $i$ at the end of the reporting year

Sal_G $=$ Sales growth of company i $\left[\left(\operatorname{Sales}_{\mathrm{t}}-\operatorname{Sales}_{(\mathrm{t}-1)}\right) / \operatorname{Sales}_{(\mathrm{t}-1)}\right]$ 
$\varepsilon_{\mathrm{i}}=$ error .

$\alpha=$ regression intercept.

$\beta_{1}, \beta_{2}, \ldots \ldots \ldots \ldots, \beta_{5}=$ Coefficients of the explanatory variables.

\section{Study 2: Association between climate change disclosures and firm value}

After finding the determinants, this research tries to find the value relevance of climate change disclosures. Here, the second study investigates the effect of disclosures on the firm value. To measure the firm value, this study uses the market to book assets ratio as a proxy of firm value. The market to book equity is also used to increase the robustness' of the firm value variable. In many previous studies on environmental and CSR disclosures, firm value is used as a dependent variable. Firms' values are often measured as the market value of the equity in many studies (Cormier \& Magnan, 2007; Matsumura et al., 2014; Cho et al., 2015). As discussed in the hypothesis development section, research on the relationship between environmental disclosures and firm value gave a mixed result, i.e. both positive and negative association are found between environmental disclosures and firm value.

That is why this study hypothesizes that:

$\mathrm{H}_{2}$ : The extent of the climate change disclosure has (positive/negative) effect on the firm value The following equation is used as a regression model for Study 2:

$\mathrm{FV}_{\mathrm{i}}=\alpha+\beta_{1}\left(\mathrm{DCCI}_{\mathrm{i}}\right)+\beta_{2}\left(\mathrm{SIZE}_{\mathrm{i}}\right)+\beta_{3}\left(\right.$ LEVERAGE $\left._{\mathrm{i}}\right)+\beta_{4}\left(\mathrm{ROA}_{\mathrm{i}}\right)+\beta_{5}\left(\mathrm{ROE}_{\mathrm{i}}\right)+\varepsilon_{\mathrm{i}}$

$\mathrm{FV}_{\mathrm{i}}=$ Firm Value of company $\mathrm{i}$.

$\mathrm{DCCI}_{\mathrm{i}}=$ Disclosure on Climate Change Issues for company $\mathrm{i}$.

$\mathrm{SIZE}_{\mathrm{i}}=$ Total assets of company $i$. This is a representation of company size.

LEVERAGE $\mathrm{i}_{\mathrm{i}}=$ leverage of company $i$. It is found through the ratio of total debt to stockholders' equity. 
$\mathrm{ROA}_{\mathrm{i}}=$ Return on Assets of company $\mathrm{i}$ at the end of the reporting year 2017

$\mathrm{ROE}_{\mathrm{i}}=$ Return on Equity of company $i$ at the end of the reporting year 2017

$\varepsilon_{\mathrm{i}}=$ error.

$\alpha=$ regression intercept.

$\beta_{1}, \beta_{2}, \ldots \ldots \ldots \ldots . . . ., \beta_{5}=$ Coefficients of the explanatory variables.

Control Variables: This research controls some independent variables that have been identified in the previous literature. Those variables are affecting the firms' environmental disclosures.

Firm Size: From the literature, it is evident that firm size is a favorite independent variable in environmental disclosure literature (Freedman \& Jaggi, 2005; Stanny \& Ely, 2008; PradoLoranzo et al., 2009). In many works of literature, it was said that the bigger companies are under greater public scrutiny, and they always try to avoid conflict. As a result, they always went for higher disclosures (Freedman \& Jaggi, 2005; Prado-Lorenzo et al., 2009). So, this study controls the effect of firm size in both the studies. Usually, the firm size measured in the literature is total assets and sales. This study measures the firm size by the logarithm of total assets.

Company performance: According to stakeholder theory, the relationship between climate change disclosures (which is a part of CSR disclosures) and firm profitability is expected to be positive since the firm has to satisfy its stakeholders thus more likely to achieve financial success. Several studies focused on the relationship between profitability and disclosures on climate change reporting. In most of the studies, it is found that there is a significant association between voluntary disclosure and profitability (Stanny \& Ely, 2008; Prado-Lorenzo et al., 2009). Following the prior research on voluntary disclosures of information, this study also controls the profitability of the firms. ROA and ROE are common measures to represent the profitability of 
the firm (Stanny \& Ely, 2008; Prado-Loranzo et al., 2009). In this study, profitability is measured by the Return on Equity (ROE) and Return on Assets (ROA).

Leverage: Leverage is another popular measure used in climate change reporting literature. It is usually measured as the debt-equity ratio. In many voluntary disclosures studies, the leverage ratio is used as an independent variable (Freedman \& Jaggi, 2005). Following the previous research (Stanny \& Ely, 2008; Prado-Loranzo et al., 2009), this study also controls for the effect of leverage. Here, leverage is measured by the debt to equity ratio.

Cross-listing: Previous climate change accounting research showed that cross-listing effect influenced the level of disclosures (Luo, Lan, \& Tang, 2012; Ben-Amar \& McIlkenny, 2015). Following those previous research, this study also controls the effect of cross-listing. In this study, cross-listing is measured by binary values, i.e., 1 if the firm is cross-listed on the TSX and US stock exchange /NYSE /NASDAQ, 0 otherwise. 


\section{Result and Analysis}

This part explains the result and findings. Section 4.1 explains the results of content analysis and possible explanations for the lack of climate change-related disclosures. Section 4.2 discusses the regression results and section 4.3 explains the findings with reference to two hypotheses.

\subsection{Stage one: Content analysis}

This part is investigating whether the oil and gas companies in Canada publicly provide information about the existence, or non-existence, of particular climate change-related issue. Most of the disclosure issues are voluntary. Shareholders cannot assess the risk of climate change if organizations fail to disclose climate change issues. A total of 16 climate change related issues under five general themes, were taken for the content analysis. Companies who scored more (maximum possible score is 16) are considered to provide higher disclosures related to climate change.

\subsubsection{Disclosures by total:}

Table 5 shows the result of the total score by the sample companies. A total of 58 companies are considered and a total of 16 climate change related issues were taken for the content analysis. Disclosure scores are calculated based on the binary values, i.e., 1 for the disclosure of a particular item and 0 for nondisclosure. Percentages are calculated by dividing the number of companies disclosed to the total number of companies i.e., 58. The result shows that only a few companies have very good disclosures about the climate changes issues. Out of 58 companies, only ten companies have a score of 10 or more, only seven companies have a score of 5 to 9 , and the rests have a score of below 5 . 
Table 5: Climate change related to total disclosures by Oil \& Gas companies

\begin{tabular}{|l|l|l|}
\hline Disclosures scores & Number of companies & Percentages \\
\hline Below 5 & 41 & $71 \%$ \\
\hline 5 to below 10 & 7 & $12 \%$ \\
\hline 10 and above & 10 & $17 \%$ \\
\hline
\end{tabular}

\subsubsection{Disclosures by categories}

Table 6 represents the findings of content analysis about the specific climate change disclosures

by the sample companies. Number column indicates how many companies disclosed the specific issue out of 58 companies. Percentages are calculated by dividing the number of companies disclosed to the total number of companies i.e., 58 .

Table 6: Climate change-related disclosures by categories by Oil \& Gas companies

\begin{tabular}{|c|c|c|}
\hline Issue & Number & Percentages \\
\hline \multicolumn{3}{|l|}{ Board oversight \& Management responsibility } \\
\hline $\begin{array}{l}\text { 1. The organization has a specific board committee to oversee the } \\
\text { environmental affairs }\end{array}$ & 15 & $26 \%$ \\
\hline $\begin{array}{l}\text { 2. The organization has a specific board committee on climate change and } \\
\text { GHG-related issues }\end{array}$ & 3 & $5 \%$ \\
\hline $\begin{array}{l}\text { 3. CEO/chairperson expresses the organization's views on the issue of climate } \\
\text { change through publicly available documents such as annual reports, } \\
\text { sustainability reports, and websites. }\end{array}$ & 47 & $81 \%$ \\
\hline \multicolumn{3}{|l|}{ Emission Accounting } \\
\hline 4. The organization report GHG in $\mathrm{CO}_{2}$ equivalent & 22 & $38 \%$ \\
\hline 5. Reporting of Scope 1 (direct) and Scope 2 (Indirect) $\mathrm{CO}_{2}$ emissions & 17 & $29 \%$ \\
\hline $\begin{array}{l}\text { 6. Report total quantity of energy consumed in oil and gas operations or other } \\
\text { business activities }\end{array}$ & 12 & $21 \%$ \\
\hline 7. $\quad$ Report the quantity of hydrocarbon gas flared from operations. & 12 & $21 \%$ \\
\hline $\begin{array}{l}\text { 8. Report total volume of freshwater withdrawn and Report the total volume of } \\
\text { freshwater consumed. }\end{array}$ & 16 & $28 \%$ \\
\hline 9. Total quantity, in metric tons, of hazardous waste, disposed. & 12 & $21 \%$ \\
\hline $\begin{array}{l}\text { 10. A section in annual report/Annual Information Form devoted to climate } \\
\text { change or global warming }\end{array}$ & 56 & $97 \%$ \\
\hline $\begin{array}{l}\text { 11. The organization has set an emission baseline year by which to estimate } \\
\text { future GHG emission trends. }\end{array}$ & 15 & $26 \%$ \\
\hline 12. Methodologies used to calculate or measure emissions & 5 & $9 \%$ \\
\hline $\begin{array}{l}\text { 13. The organization has third-party verification processes for GHG emission } \\
\text { data. }\end{array}$ & 6 & $10 \%$ \\
\hline \multicolumn{3}{|l|}{ Research and Development } \\
\hline $\begin{array}{l}\text { 14. The organization has the policy to develop alternative/ renewable energy } \\
\text { such as Nuclear, solar, hydropower and wind energy }\end{array}$ & 7 & $12 \%$ \\
\hline
\end{tabular}




\begin{tabular}{|c|l|l|}
\hline Reporting Benchmark & & $19 \%$ \\
\hline $\begin{array}{c}\text { The organization has the policy to comply with GRI guidelines and/or } \\
\text { GHG Protocol standard }\end{array}$ & 11 & $19 \%$ \\
\hline Potential Liability Reduction & & $12 \%$ \\
\hline $\begin{array}{c}\text { The organization has a policy to minimize the potential regulator risk and } \\
\text { physical threats to assets related to climate change }\end{array}$ & 7 & \\
\hline
\end{tabular}

Figure 3 represents the disclosure of five broad categories for the year 2017.

Figure 3: Disclosures percentages of specific issues

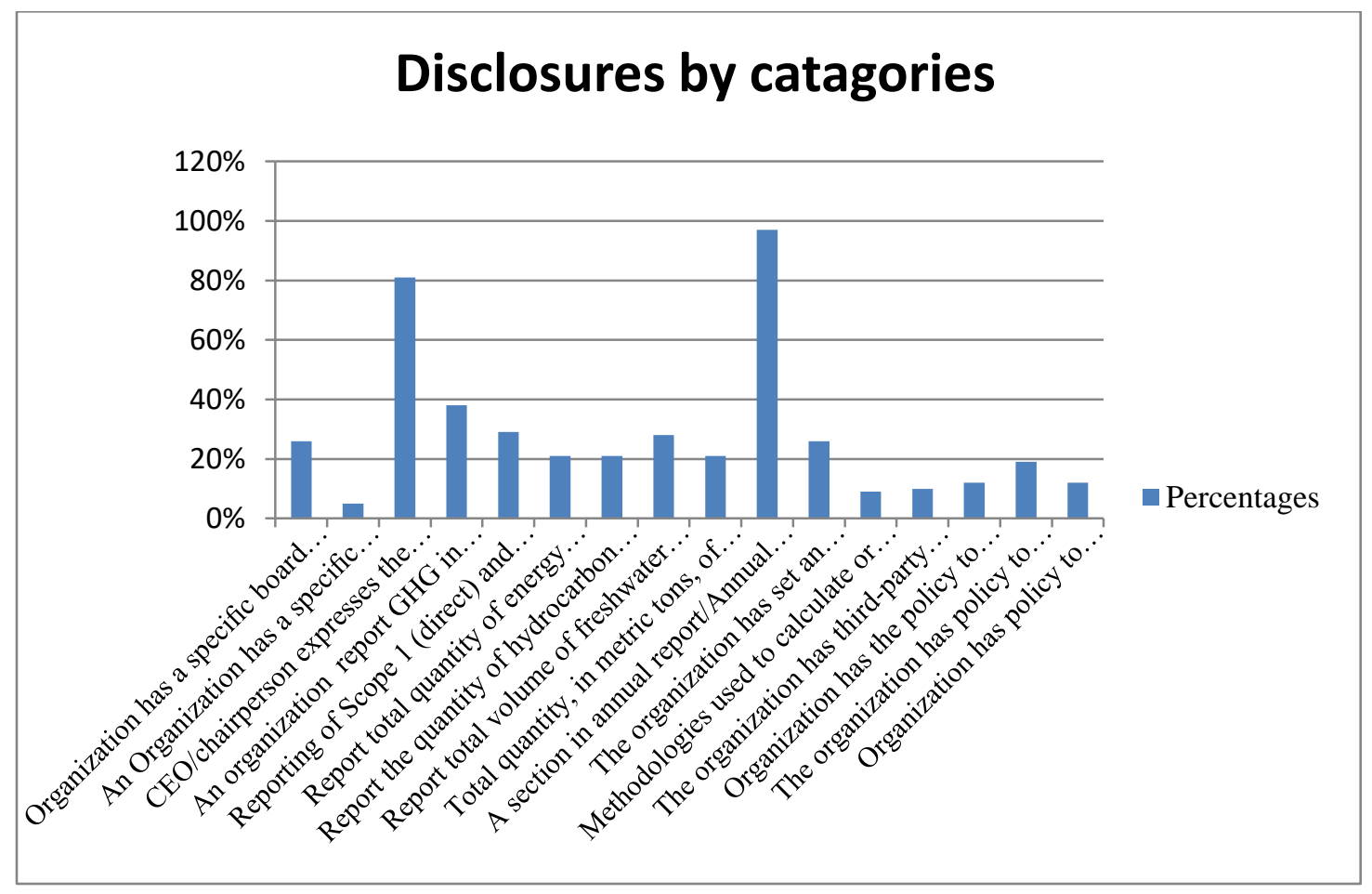

\section{a) Board-oversight and Management responsibilities:}

Findings show that most of the sample companies have very poor oversight and management responsibility related to disclosures. Only 15 companies have a separate committee who oversee the environmental-related issue and only three companies have a committee to oversee the climate change pertaining matters. CEO's opinion on the climate change issue has got the highest importance $(81 \%)$ from sample companies.

\section{b) Emission Accounting:}


Disclosure percentages about the emission accounting are also poor for the sample companies. Table 2 shows a separate section in the annual report/annual information form got the highest importance from the sample companies. Twenty-two companies report about the GHG in $\mathrm{CO}_{2}$ equivalent out of 58 sample companies. Company reporting on other issues on emission accounting are direct and indirect emission is $29 \%$, freshwater withdrawn and consumed is $28 \%$, the organization has an emission baseline is $26 \%$. Out of 58 companies, 12(21\%) companies reported on a total quantity of energy consumed the quantity of hydrocarbon gas. Only five companies $(6 \%)$ disclosed their methodologies used to calculate or measure emissions. Third party verification (audit) of GHG emission data was done only six companies (10\%).

\section{c) Research and Development}

If the organization has the policy to develop alternatives/ renewable energy such as nuclear, solar, hydropower and wind energy and it is mentioned explicitly in the report, then it is regarded as research and development related disclosures. Only seven companies out of 58 companies have such type of plan and they specifically mentioned in the publicly available documents.

\section{d) Reporting Benchmark}

Reporting benchmarks is whether the organization has the policy to comply with GRI guidelines and/or GHG Protocol standard. Eleven companies have complied with GRI guidelines.

\section{e) Potential Liability Reduction}

If the organization has a policy to minimize the potential regulator risk and physical threats to assets related to climate change, then it is regarded as the possible liability reduction disclosures. 
Only seven companies mentioned that they have a policy to minimize the potential regulator risk and physical threats to assets related to climate change.

\subsubsection{Discussion on Content analysis:}

The result of the content analysis concludes that climate change reporting by oil and gas companies is still at a low level. Some issues have been well disclosed, for example, issues under 'board oversight \& management responsibility' and 'emissions accounting.' Except a few, no company has provided disclosures with all of the issues identified which can be viewed as 'best practice.' Most of the companies provided minimal disclosures. The analysis shows that almost $71 \%$ of the sample firms provided disclosures about 5 or less issue out of 16 disclosures issues.

Oil and gas sector is the largest emitter of the GHG in 2017 (Climate Change Canada, 2017). Thus disclosure issues on climate changes are significant for the stakeholders. These poor disclosures would not let the stakeholders know about the risks of climate change and the associated efforts by the oil and gas companies.

\subsubsection{Explanations of the lack of climate change disclosures:}

One possible reason for poor disclosures may be the absence of accounting standards for accounting for GHG emission for Canadian companies. The only reporting regulation for the listed companies in Canada is IAS 37. International Financial Reporting Interpretations Committee (IFRIC) issued IFRIC 3 Emission Rights24. It was withdrawn by the International Accounting Standards Board because of the pressure from various groups (Haque, 2011).

Another possible explanation is the lack of proper guidance by Canadian Securities Administrators (CSA). CSA issued environmental reporting guidelines for listed companies of TSX in 2010. There are detailed guidelines for companies to disclose environmental disclosures like material information, environmental risk and related matters, risk oversight, and 
management (CSA, 2010). There are no specific guidelines for the companies to disclose climate change related information. Recently CSA announced a project to review the climate change disclosures. Major objective of the project is to assess whether the current security legalization and guidance are sufficient for the issuer to determine the climate change related disclosures (CSA, 2018).

Thus it can be expected that the research reported in this stage, which highlights the lack of disclosure, might hopefully stimulate Canadian oil and gas companies to increase the extent of disclosures on reporting and managing of climate change.

\subsection{Stage two: Regression Analysis}

In this part, regression analyses have been conducted to find out the research objective two and three. Study 1 investigates the relationship between the disclosure of climate change issues and boards' effectiveness (measured by BSCI index).

Descriptive Statistics: Descriptive statistics for the variables of study 1 is presented in Table 7 :

Table 7: Descriptive statistics of variables of study 1

\begin{tabular}{|l|r|r|r|r|r|r|}
\hline Variable & N & \multicolumn{1}{l|}{ Mean } & \multicolumn{1}{l|}{ Sd } & \multicolumn{1}{l|}{ p25 } & \multicolumn{1}{l|}{ p50 } & \multicolumn{1}{l|}{ 775 } \\
\hline Total DCCI & 57 & 7.11 & 4.65 & 3.00 & 8.00 & 11.00 \\
\hline BSCI_Index & 57 & & & & & \\
\hline Size & 57 & 8.49 & 1.37 & 7.32 & 8.00 & 9.23 \\
\hline ROA & 57 & -0.03 & 0.10 & -0.04 & -0.01 & 0.02 \\
\hline Leverage & 57 & 0.20 & 0.11 & 0.13 & 0.18 & 0.25 \\
\hline List_Dual & 57 & 0.05 & 0.23 & 0.00 & 0.00 & 0.00 \\
\hline Sale_Growth & 36 & 0.16 & 0.35 & -0.07 & 0.08 & 0.44 \\
\hline
\end{tabular}


Table 7 shows the descriptive results of mean, standard deviation and percentile of the data set. Average disclosure on climate changes issues is 7.1 (out of a maximum possible total score of 16) which indicate a very poor score on the disclosures by the sample companies. This poor score on climate change issues is in line with the previous studies of Berthelot and Robert's (2011) study on Canadian oil \& gas companies.

The descriptive statistics for the primary variable of interest (BSCI) demonstrate that index is 110 (Out of a total of 150). The average score is almost $73 \%$, which indicates that the BSCI index of sample companies is B grade as per the BSCI measures. The result is comparable to those reported by Ben-Amar and McIlkenny (2015). Only a few companies have a perfect score on BSCI. There is much variability (20\%) among the board effectiveness among the oil and gas companies. This high variability has also supported the argument on Ben-Amar and McIlkenny (2015) that the Canadian companies variability in the perceived board effectiveness because they only required to disclose their compliance with corporate governance 'best practices' guidelines rather than to implement them.

Regarding the control variables, table 6 shows the mean value of size proxy is 8.49 which is equivalent to 4866 million, indicating that the sample included relatively larger firms. The mean value of ROA is -.03 (range from -.04 to .02) shows that the sample contains performing and non- performing firms. Sales growth is included in the model because firms that expect higher growth may need additional financing and may, therefore, disclose more to reduce the cost of adverse selection.

Table 8: Correlation Matrix of all variables of the study 1

\begin{tabular}{|l|l|l|l|l|l|l|l|}
\hline & $\begin{array}{l}\text { Total } \\
\text { DCCI }\end{array}$ & BSCI_Index & Size & ROA & Leverage & ListDual & SaleGrowth \\
\hline Total DCCI & 1.00 & & & & & & \\
\hline
\end{tabular}




\begin{tabular}{|l|r|r|r|r|r|r|r|}
\hline BSCI_Index & 0.58 & \multicolumn{1}{|c|}{1.00} & & & & & \\
\hline Size & 0.74 & 0.37 & 1.00 & & & & \\
\hline ROA & 0.36 & 0.06 & 0.08 & 1.00 & & & \\
\hline Leverage & 0.19 & 0.17 & 0.34 & -0.22 & 1.00 & & \\
\hline List_Dual & 0.10 & 0.20 & 0.21 & 0.18 & 0.11 & 1.00 & \\
\hline Sale_Growth & -0.28 & -0.32 & -0.16 & 0.06 & -0.12 & 0.27 & 1.00 \\
\hline
\end{tabular}

Correlation coefficients between the variables are shown in Table 8. As shown in the table, the correlation between the dependent variable (DCCI) and the main variable of interest (BSCI) is .58 , which indicates that they are positively related. This finding supports the hypothesis that there is a positive relationship between the extent of board effectiveness and climate change disclosure.

Likewise, BSCI is positively associated with the control variables of size, profitability, leverage and negatively with the sales growth. Control variables of Size and ROA are positively correlated with the BSCI also are in line with the previous studies (Freedman and Jaggi, 2005; Prado-Lorenzo et al., 2009). However, a low level of association is found with leverage and cross- listing.

Table 8 also shows that there is no substantial correlation between predictors. The correlations between explanatory variables are well below the critical value (.7). This low level of associations between explanatory variables indicates no evidence of multicollinearity.

\section{Regression analysis:}

The result of the regression analysis for study 1 is presented in table 9 where BSCI index is used as the explanatory variable and disclosures on climate change (DCCI) is the dependent variable. Dependent variable (DCCI) was transformed to log to make the distribution closer to a normal 
distribution and more appropriate for regression.

Table 9: Regression result of study 1

\begin{tabular}{|c|c|c|c|c|}
\hline \multirow[b]{2}{*}{ Ind. Variables } & \multicolumn{4}{|c|}{ Dep. Variable: $\log$ Score of DCCI } \\
\hline & (1) & $(2)$ & $(3)$ & $(4)$ \\
\hline BSCI_Index & $\begin{array}{c}0.026 * * * \\
(6.44)\end{array}$ & $\begin{array}{c}0.018 * * * \\
(4.78)\end{array}$ & $\begin{array}{c}0.018 * * * \\
(4.58)\end{array}$ & $\begin{array}{c}0.016 * * * \\
\quad(3.57)\end{array}$ \\
\hline Size & & $\begin{array}{c}0.334 * * * \\
(5.91)\end{array}$ & $\begin{array}{c}0.329 * * * \\
(5.71)\end{array}$ & $\begin{array}{c}0.356^{* * * *} \\
(5.43)\end{array}$ \\
\hline ROA & & $\begin{array}{l}-0.904 \\
(-1.13)\end{array}$ & $\begin{array}{l}-0.711 \\
(-0.81)\end{array}$ & $\begin{array}{c}6.218 * * * \\
(2.90)\end{array}$ \\
\hline Leverage & & $\begin{array}{c}-1.162 * \\
(-1.68)\end{array}$ & $\begin{array}{l}-1.169 \\
(-1.66)\end{array}$ & $\begin{array}{l}-0.608 \\
(-0.74)\end{array}$ \\
\hline ListDual & & $\begin{array}{l}-0.241 \\
(-0.80)\end{array}$ & $\begin{array}{l}-0.137 \\
(-0.40)\end{array}$ & $\begin{array}{l}-0.261 \\
(-0.82)\end{array}$ \\
\hline SaleGrowth & & & & $\begin{array}{l}0.506 \\
(1.13)\end{array}$ \\
\hline Constant & $\begin{array}{c}-1.244 * * * \\
(-2.69)\end{array}$ & $\begin{array}{c}-2.904 * * * \\
(-6.22)\end{array}$ & $\begin{array}{c}-2.775 * * * \\
(-5.55)\end{array}$ & $\begin{array}{c}-2.960 * * * * \\
(-4.71)\end{array}$ \\
\hline Observations & 57 & 57 & 57 & 36 \\
\hline Adjusted R-squared & 0.419 & 0.630 & 0.620 & 0.683 \\
\hline Winsorized & Yes & Yes & Yes & Yes \\
\hline Year Fixed Effect & No & No & Yes & Yes \\
\hline
\end{tabular}

As shown in table 9, BSCI has a positive association with disclosures controlling all the other variables known to affect disclosures.

The first column shows the result without the effect of control variables. The result shows that dependent variable DCCI is significant to the primary variable of interest, BSCI. In the second column, the effects of control variables are added, and the result is still significant to BSCI. The control variable size is a significant predictor of disclosures showing that larger oil and gas 
companies produce a significantly more extensive report on climate changes. In the third column, year fixed effect and in fourth column effect of sales growth are incorporated, and still, it is found that the result is significant. Effects of control variables (column 2), fixed effect (colmn3), and sales growth (column 4) do not change the inferences.

The findings support the hypothesis that the board-shareholder confidence index significantly affects the disclosures on climate changes by the oil and gas companies. This empirical finding implies that Canadian oil and gas companies with an excellent board-shareholder confidence index are more likely to disclose more information on climate changes issues.

The second study explores the relationship between climate change disclosures and Firm Value(FV).

Descriptive Statistics: Descriptive statistics for the variables of the second study is presented in Table 10.

Table 10: Descriptive Statistics of variables of study 2

\begin{tabular}{|c|c|c|c|c|c|c|}
\hline Variable & $\mathbf{N}$ & Mean & SD & p25 & p50 & p75 \\
\hline Total DCCI & 58 & 4.67 & 4.46 & 2.00 & 2.00 & 8.00 \\
\hline $\begin{array}{l}\text { Market to Book } \\
\text { Assets }\end{array}$ & 58 & 0.68 & 0.62 & 0.33 & 0.53 & 0.85 \\
\hline Market to equity & 58 & 1.21 & 1.07 & 0.54 & 0.88 & 1.60 \\
\hline Size & 58 & 7.00 & 1.90 & 5.64 & 7.11 & 8.00 \\
\hline Leverage & 58 & 0.42 & 0.18 & 0.29 & 0.40 & 0.52 \\
\hline $\mathrm{ROA}$ & 58 & -0.04 & 0.15 & -0.07 & 0.00 & 0.04 \\
\hline $\mathrm{ROE}$ & 58 & -0.13 & 0.43 & -0.14 & 0.00 & 0.07 \\
\hline
\end{tabular}

The descriptive result shows the mean, standard deviation, and percentile of the data set. The dependent variables of Firm Value (FV) are denoted by Market to Book assets and Market to Equity. The result indicates that the average disclosure score on climate changes issues are 4.6 (out of a total score of 16). The result shows that the overall rating on the issue of disclosure is lagging. This poor score on climate change issues is in line with the previous studies (e $\mathrm{g}$ Berthelot \& Robert, 2011). 
Regarding the control variables, table 10 shows that the mean value of the size proxy is seven, indicating that the sample included relatively larger firms. The mean value of ROA and ROE are -.04 and -.13 respectively. Their ranges suggest that the sample contains performing and nonperforming firms.

Table11 presents the correlation coefficients between the variables.

Table 11: Correlation Matrix of all variables of study 2

\begin{tabular}{|l|r|r|r|r|r|r|r|}
\hline & $\begin{array}{l}\text { Total } \\
\text { DCCI }\end{array}$ & $\begin{array}{l}\text { Market to } \\
\text { Book } \\
\text { Assets }\end{array}$ & $\begin{array}{l}\text { Market } \\
\text { to } \\
\text { equity }\end{array}$ & Size & Leverage & ROA & ROE \\
\hline $\begin{array}{l}\text { Total } \\
\text { DCCI }\end{array}$ & 1.00 & & & & & & \\
\hline $\begin{array}{l}\text { Market to } \\
\text { Book } \\
\text { Assets }\end{array}$ & 0.15 & 1.00 & & & & & \\
\hline $\begin{array}{l}\text { Market to } \\
\text { equity }\end{array}$ & 0.12 & 0.81 & 1.00 & & & & \\
\hline Size & 0.71 & 0.03 & -0.07 & 1.00 & & & \\
\hline Leverage & 0.02 & -0.37 & 0.09 & -0.06 & 1.00 & & \\
\hline ROA & 0.33 & 0.21 & 0.04 & 0.44 & -0.27 & 1.00 & \\
\hline ROE & 0.32 & 0.19 & -0.24 & 0.50 & -0.53 & 0.76 & 1.00 \\
\hline
\end{tabular}

As shown in table 11, the correlation between the independent variable (DCCI) and dependent variables (represented by the market to book assets and market to book equity) are .15 and .12 respectively, which indicates that they are positively associated with each other. This finding supports the hypothesis that there is a positive relationship between climate change disclosure and firm value.

The table shows that there is no substantial correlation between predictors. There is a small correlation found between DCCI and Market to Book assets and Market to Equity. Table 11 also shows that relationships between explanatory variables are well below the critical value (.7). 
This low level of associations between explanatory variables indicates no evidence of multicollinearity.

\section{Regression analysis:}

The regression result of study 2 is presented in table 12 .

Table 12: Regression result of study 2

\begin{tabular}{lccc}
\hline Dep. Var $\longrightarrow$ & logScore & Mkt2BookEquity & Mkt2BookAssets \\
Ind. Variables & $(1)$ & $(2)$ & $(3)$ \\
\hline \multirow{2}{*}{ logScore } & & $0.408^{*}$ & $0.243^{*}$ \\
Size & $0.318^{* * *}$ & $(1.89)$ & $(1.91)$ \\
& $(6.09)$ & -0.092 & -0.075 \\
Leverage & -0.002 & $(-0.86)$ & $(-1.19)$ \\
& $(-0.00)$ & -1.079 & $-1.490^{* * *}$ \\
ROA & 0.363 & $(-1.16)$ & $(-2.72)$ \\
& $(0.42)$ & $3.812^{* * *}$ & 1.056 \\
ROE & -0.024 & $-1.971 * * *$ & $(1.33)$ \\
Constant & $(-0.07)$ & $(-3.41)$ & -0.345 \\
& $-1.064 * *$ & $1.720 * *$ & $(-1.01)$ \\
Observations & $(-2.66)$ & $(2.58)$ & $1.552^{* * *}$ \\
Adjusted R-squared & & & $(3.94)$ \\
\hline
\end{tabular}

t-statistics in parentheses

$$
* * * \mathrm{p}<0.01, * * \mathrm{p}<0.05, * \mathrm{p}<0.1
$$

The regression result for study 2 is significant. Dependent variable market to book assets and market to book equity both are significant to the primary variable of interest (DCCI) at a 10 percent level of significance. The result signifies that the firm's value positively reacts to the disclosures of climate change information by the sample companies. The findings support the hypotheses that climate change disclosures significantly affect the firm values of the oil and gas companies. However, both the coefficients' positive values indicate that the market responds positively to the climate change disclosures, thus, there is a value relevance of the climate 
change disclosures.

There is no significant association between the control variable, size, and firm value. The regression result is significant in relation to the control variables of profitability (measured by ROA and ROE) and leverage. It signifies that there is a significant association with profitable and levered firms with the enterprises' value.

\subsection{Discussion of findings:}

\subsubsection{Board's effectiveness and climate change disclosures:}

The result of the study one shows that there is a positive association between perceived board effectiveness and disclosures on climate change. This result suggests that the board effectiveness of oil and gas companies in Canada affects the extent of disclosures on climate changes to the stakeholders. Effective boards will disclose more information on climate change issues.

The result is consistent with the previous study Switzer and Cao (2011) and Ben-Amar and McIlkenny (2015) who got a significant relationship between BSCI index with firm performance and voluntary disclosures of climate change information (CDP questionnaire) respectively.

The result supports the agency theory. Governance literature shows that effective boards play an important role in monitoring managerial actions, which in turns reduce agency problems and improve the information environment (Cheng \& Courtenay, 2006). The result of this study supports that firms with an active board are more likely to disclose climate change issues than that of the firms with fewer effective boards. Management does this to ensure the symmetrical information in the market. Hence, board effectiveness, by way of reducing agency problem, enhance disclosures on climate change issues.

It also supports stakeholder's theory perspective that board effectiveness significantly influences the likelihood of voluntary reporting on climate change issues. Board effectiveness is crucial in satisfying the demand of different stakeholders groups (Hillman, Keim, \& Luce, 2001). Firms 
with effective boards will disclose more climate change information to satisfy the stakeholders. Finally, this study confirms previous literature that corporate board plays a vital role in ensuring organizational legitimacy through corporate disclosures (Khan, Muttakin, \& Siddiqui, 2013).

The findings fit with the previous studies which show that company size is related to the extent of GHG reporting (Freedman \& Jaggi 2005; Stanny \& Ely, 2008; Prado Lorenzo et al., 2009). Larger firms have more disclosures about GHG emissions, which explain their higher propensity to respond to disclose more climate change issues to the stakeholders compare to smaller companies.

The regression result is significant to the control variables of profitability (measured by ROA). The result suggested that profitable firms may have more resources to devote to GHG emission measurement and reporting than financially troubled firms. There is no significant association between cross-listing and disclosures of climate change. It means that firms listed in more stock exchange (like TSX and NYSE) would not provide more information about the climate change issue. However, the findings contradict with previous studies (see: Ben-Amar \& Mcllkenny, 2015), which found a significant association between cross-listed firms and climate change disclosures. No significant association may be explained that companies cross-listed in separate stock exchange do not report more in comparison to Canada. The result also signifies that there is no significant association between the levered firms with the reporting of GHG. Interestingly this result contradicts with many of the previous research (see: Stanny \& Ely, 2008; PradoLoranzo et al., 2009) who find a positive relationship between leverage and voluntary disclosures of information. This insignificant association can be explained that highly leveraged firms in the sample do not differ significantly in disclosing climate change initiative compared to a less leveraged firm. 


\subsubsection{Climate change disclosures and Firm Value:}

In the second study, the results show that there is a significant relationship between climate change disclosures and firm value. It reveals that climate change disclosures will positively affect the market value of the firm.

Disclosures of more climate change information will be more likely to boost the market value of the companies. The findings are more consistent with the prior studies (Clerkson et al., 2013; Cormier \& Magnan, 2015; Plumlee et al., 2015), which showed that reporting of environmental information would be more likely to increase the market performance of the companies. The findings support the previous research of the positive relationship between voluntary disclosures of information and market performance of the firms.

This result can be interpreted from economic significance. The coefficients of the market to book and market to equity are .408 , and .243 respectively which imply that an increase in climate change disclosures are valued positively. The result suggests that a proactive measure in climate change and signaling to the stakeholders can enhance the firm's value.

The findings also support stakeholder's theory. Shareholders are the major stakeholders and they are primarily concerned with the expected future profitability of the company (Cormier \& Magnan, 2015). The positive association between environmental disclosures and enterprise values supports the theory that stakeholders positively valued the firm's climate change disclosures initiatives in term of high market value of the firm.

Although the study result shows that climate -change disclosures and firm value are positively related to each other, two caveats are necessary. First, the relationship between disclosures and firm-value is marginally significant at $10 \%$ level; thus the result is not very strong statistically. 
This is likely because this study has very few observations (58) and therefore has low power. Second, the final sample size of the study is 58, which may raise concern with the generalizability of findings from the study. Therefore, findings form the study should be interpreted with caution.

In summary, this study concludes the following:

Firstly: Climate change reporting by the oil and gas companies in Canada is still at a low level. One possible explanation for these poor disclosures may be the absence of accounting standards for GHG emission for Canadian companies.

Secondly: The high and positive association between board effectiveness and climate change disclosures supports the idea that only a few companies, which have efficient boards, will have very good disclosures on emission. Companies with less effective boards would be less likely to disclose their initiatives about climate change.

Thirdly: The relationship between climate change disclosures and firm value indicates that the investors consider the extent of disclosures on climate changes when they assess the market value of the firms. 


\section{Conclusion}

This part provides a summary of the research findings and recommendations followed by research limitations and the scope for future research.

\subsection{Research findings and Implications \& Recommendations:}

There are two interrelated research stages (content analysis and regression analyses) in this study. Each stage has particular implications for environmental accounting literature. The main findings and implications in each stage are discussed as follows.

Stage one makes a content analysis of the climate change disclosures of the oil and gas companies listed in TSX. This stage contributes to the environmental accounting literature as it gives an overview of the climate change disclosures practices of Canadian oil and gas companies. The findings concluded that climate change disclosures by oil and gas companies in Canada are still at a low level. Findings of this content analysis will hopefully act as a stimulus for the oil and gas companies. It is expected that if companies increase the disclosures of their climate change-related practices, then this would conform to stakeholders' expectations about accountability to climate change.

CSA is going to implement a project on the disclosure of climate change (CSA, 2018). The outcome of this analysis will help CSA to have insight into climate change disclosures practices and provide a frame of references for developing requirement of disclosures.

In stage two, this research investigates the relationship between the disclosure of climate change issues and the corporate governance variables (BSCI index) for Canadian oil \& gas companies. The high and positive association between board effectiveness and climate change disclosures exhibits that firm with good board corporate governance will disclose more to their stakeholders. 
The result supports the idea that only a few companies, which have efficient boards, will have very good disclosures on emission.

This research also explores the relationship between climate change disclosures and firm value. The empirical evidence indicates that the extent of disclosures on climate changes do matter to the investors regarding the high market value of the firms. Findings should encourage Canadian oil and gas companies to reduce carbon emissions and to disclose their carbon management activities.

\subsection{Research Limitations:}

This research is not without limitations. The following are some of the limitations I have encountered.

Firstly, the study covers only 58 firms for the year 2017 to find the relationship between climate change disclosures and firm values. A large sample size could provide more insightful information about the climate change disclosures.

Secondly, this study focuses on only Canadian oil and gas firms. The result of this study should not be extended to other sectors or other countries.

Thirdly, the binary scoring system has its limitations. It gives equal weight for each item irrespective of their nature and importance. For example, if an item is reported, its score is 1, without going for the extent of discussion. As a result, detailed discussion is ignored. However, such a scoring system (presence or absence of disclosure) requires a lesser degree of judgment (Milne \& Adler, 1999).

Fourthly, board effectiveness is measured by BSCI (Board Shareholders' Confidence Index) for this study. BSCI data are available for 22 companies from the year 2015 to 2017. To make a longitudinal study, only those 22 companies are considered for the study. On top of that, Ben Omar and McIlkenny (2015) said that BSCI does not consider green governance practices. They 
stated that despite not having green governance, BSCI is good to measure the effectiveness of the board of directors.

Finally, the good environmental performers and bad environmental performers are not segregated in the second study. Clarkson et al. (2004) review the environmental economics literature that suggests two environmental performance types: good environmental performers and bad environmental performers. However, separate value relevance of both good and bad performers of climate change disclosures would give a fascinating insight, which was absent in this research.

\subsection{Scope for future research:}

There are some specific issues that are subject to further research that stems from this study. Firstly, stage one of this research investigates the climate change disclosures practices of oil and gas companies listed in TSX. Further research would utilize this index on a large number of companies, including the entire emission-intensive sector. It will be interesting to investigate whether the findings can be applied more broadly for other emissions-intensive sectors.

Secondly, this research does not separate the good and bad performers and their value relevance. Separate value relevance of both good and bad performers of climate change disclosures would give a fascinating insight which was absent in this research. This segregation will demand future research. 


\section{References}

Bansal, P., \& Clelland, I. (2004). Talking trash: Legitimacy, impression management, and unsystematic risk in the context of the natural environment. Academy of Management Journal, 47(1), 93-103.

Bebbington, J. \& Larrinaga-Gonzalez, C. (2008). Carbon trading: accounting and reporting issues. European Accounting Review, 17(4), 697-717.

Bebbington, J., Schneider, T., Stevenson, L., \& Fox, A. (2019). Fossil fuel reserves and resources reporting and unburnable carbon: Investigating conflicting accounts. Critical Perspectives on Accounting, doi:10.1016/j.cpa.2019.04.004

Biel, K., \& Glock, C. H. (2016). Systematic literature review of decision support models for energy-efficient production planning. Computers \& Industrial Engineering, 101, 243-259. doi:10.1016/j.cie.2016.08.021

Berthelot, S., \& Robert, A. M. (2011). Climate change disclosures: An examination of Canadian oil and gas firms. Issues in Social and Environmental Accounting, 5(1/2), 106-123.

Ben-Amar, W., \& McIlkenny, P. (2015). Board effectiveness and the voluntary disclosure of climate change information. Business Strategy and the Environment, 24(8), 704-719.

Benston, G. J. (1982). Accounting and corporate accountability. Accounting, Organizations and Society, 7(2), 87-105.

Blacconiere, W. G., \& Patten, D. M. (1994). Environmental disclosures, regulatory costs, and changes in firm value. Journal of accounting and economics, 18(3), 357-377.

Burck, J., Marten, F., Bals, C., \& Höhne, N. (2014). The climate change performance index: results 2018. Berlin: Germanwatch.

Canada, E. A. (2016, November 19). Canada submits Mid-Century Strategy for a Clean Growth Economy. Retrieved December 27, 2017, from https://www.canada.ca/en/environmentclimate-change/news/2016/11/canada-submits-century-strategy-clean-growtheconomy.html

Canadian Securities Administrators (CSA). (2010). Environmental Reporting Guidance, Staff Notice 51-333. http://www.osc.gov.on.ca/documents/en/SecuritiesCategory5/csa_20101027_51-333_environmental-reporting.pdf

Canadian Securities Administrators (CSA). (2018). Canadian securities regulators report on climate change-related disclosure project. Retrieved from https://www.securitiesadministrators.ca/aboutcsa.aspx?id=1677

Chelli, M., Durocher, S., \& Fortin, A. (2018). Normativity in environmental reporting: A comparison of three regimes. Journal of Business Ethics, 149(2), 285-311.

Chen, C. J., \& Jaggi, B. (2000). Association between independent non-executive directors, family control and financial disclosures in Hong Kong. Journal of Accounting and Public 
policy, 19(4-5), 285-310.

Cheng, E. C., \& Courtenay, S. M. (2006). Board composition, regulatory regime and voluntary disclosure. The international journal of accounting, 41(3), 262-289.

Cho, C. H., Guidry, R. P., Hageman, A. M., \& Patten, D. M. (2012). Do actions speak louder than words? an empirical investigation of corporate environmental reputation. Accounting, Organizations and Society, 37(1), 14-25. doi:10.1016/j.aos.2011.12.001

Cho, C. H., Michelon, G., Patten, D. M., \& Roberts, R. W. (2015). CSR disclosure: the more things change...? Accounting, Auditing \& Accountability Journal, 28(1), 14-35.

Clarkson, P. M., Fang, X., Li, Y., \& Richardson, G. (2013). The relevance of environmental disclosures: are such disclosures incrementally informative? Journal of Accounting and Public Policy, 32(5), 410-431.

Climate Change Canada. (2017, April 13). Greenhouse gas emissions by Canadian economic sector. Retrieved March 26, 2018, from https://www.canada.ca/en/environment-climatechange/services/environmental-indicators/greenhouse-gas-emissions/canadian-economicsector.html

Connors, E., Johnston, H. H., \& Gao, L. S. (2013). The informational value of Toxics Release Inventory performance. Sustainability Accounting, Management and Policy Journal, 4(1), $32-55$

Cormier, D., \& Gordon, I. M. (2001). An examination of social and environmental reporting strategies. Accounting, Auditing \& Accountability Journal, 14(5), 587.

Cormier, D., Ledoux, M. J., \& Magnan, M. (2011). The informational contribution of social and environmental disclosures for investors. Management Decision, 49(8), 1276-1304.

Cormier, D., \& Magnan, M. (2007). The revisited contribution of environmental reporting to investors' valuation of a firm's earnings: An international perspective. Ecological economics, 62(3-4), 613-626.

Cormier, D., \& Magnan, M. (2015). The economic relevance of environmental disclosure and its impact on corporate legitimacy: An empirical investigation. Business Strategy and the Environment, 24(6), 431-450.

Deegan, C. (2002). Introduction: The legitimizing effect of social and environmental disclosures-a theoretical foundation. Accounting, Auditing \& Accountability Journal, 15(3), 282-311.

Downie, J., \& Stubbs, W. (2013). Evaluation of Australian companies' scope 3 greenhouse gas emissions assessments. Journal of Cleaner Production, 56, 156-163.

Eberlein, B., \& Matten, D. (2009). Business Responses to Climate Change Regulation in Canada and Germany: Lessons for MNCs from Emerging Economies. Journal of Business Ethics Vol 86, pp.241-255 
Fama, E. F., \& Jensen, M. C. (1983). Separation of ownership and control. The journal of law and Economics, 26(2), 301-325.

Freedman, M. \& Jaggi, B. (2005). Global warming, commitment to the Kyoto protocol, and accounting disclosure by the largest global public firms from polluting industries. The International Journal of Accounting, 40, 215-232.

Freedman, M., \& Jaggi, B. (2011). Global warming disclosures: impact of Kyoto protocol across countries. Journal of International Financial Management \& Accounting, 22(1), 46-90.

Friedman, M. (2002). Capitalism and freedom: fortieth anniversary edition. Retrieved from https://ebookcentral-proquest-com.ezproxy.lib.ryerson.ca

Global Reporting Initiative. (2016). GRI 305: Emissions. GRI Standards, 1-20. Retrieved from https://www.globalreporting.org/standards/gri-standards-download-center/

Haque, S., \& Deegan, C. (2010). Corporate climate change-related governance practices and related disclosures: evidence from Australia. Australian accounting review, 20(4), 317-333.

Haque, S. (2011). Climate change-related corporate governance disclosure practices: evidence from Australia. (Doctoral dissertation) Retrieved from https://researchbank.rmit.edu.au/view/rmit:160146/Haque.pdf

Hillman, A. J., Keim, G. D., \& Luce, R. A. (2001). Board composition and stakeholder performance: Do stakeholder directors make a difference?. Business \& Society, 40(3), 295314.

Intergovernmental Panel on Climate Change (2014). Climate Change 2014; Synthesis Report, Fifth Assessment Report, available at https://ar5-syr.ipcc.ch/

Jaccard, M., Rivers, N., \& Peters, J. (2009). Destined for failure? assessing canada's current climate policy. Inroads: A Journal of Opinion, (24), 55.

Jensen, M. C., \& Meckling, W. H. (1976). Theory of the firm: Managerial behavior, agency costs and ownership structure. Journal of financial economics, 3(4), 305-360.

Khan, A., Muttakin, M. B., \& Siddiqui, J. (2013). Corporate governance and corporate social responsibility disclosures: Evidence from an emerging economy. Journal of business ethics, 114(2), 207-223.

Kolk, A., Levy, D., \& Pinkse, J. (2008). Corporate responses in an emerging climate regime: The institutionalization and commensuration of carbon disclosure. European Accounting Review, 17(4), 719-745.

Labatt, S., \& White, R. R. (2011). Carbon finance: the financial implications of climate change (Vol. 362). John Wiley \& Sons.

Luo, L., Lan, Y. C., \& Tang, Q. (2012). Corporate incentives to disclose carbon information: Evidence from the CDP Global 500 report. Journal of International Financial Management \& Accounting, 23(2), 93-120. 
Matsumura, E. M., Prakash, R., \& Vera-Munoz, S. C. (2014). Firm-value effects of carbon emissions and carbon disclosures. The Accounting Review, 89(2), 695-724. doi:10.2308/accr-50629

Michelon, G., \& Parbonetti, A. (2012). The effect of corporate governance on sustainability disclosure. Journal of Management \& Governance, 16(3), 477-509.

Milne, M. J., \& Adler, R. W. (1999). Exploring the reliability of social and environmental disclosures content analysis. Accounting, Auditing \& Accountability Journal, 12(2), 237256.

Ness, K. E., \& Mirza, A. M. (1991). Corporate social disclosure: A note on a test of agency theory. The British Accounting Review, 23(3), 211-217.

Pellegrino, C. \& Lodhia, S. (2012). Climate change accounting and Australian mining industry: exploring the links between corporate disclosure and the generation of legitimacy. Journal of Cleaner Production, 36, 68-82.

Plumlee, M., Brown, D., Hayes, R. M., \& Marshall, R. S. (2015). Voluntary environmental disclosure quality and firm value: Further evidence. Journal of Accounting and Public Policy, 34(4), 336-361.

Prado-Lorenzo, J., Rodriguez-Dominguez, L., Gallego-Alvarez, I. \& Garcia-Sanchez, I. (2009).Factors influencing the disclosure of greenhouse gas emissions in companies worldwide. Management Decision, 47(7), 1133-1157.

Qiu, Y., Shaukat, A., \& Tharyan, R. (2016). Environmental and social disclosures: Link with corporate financial performance. The British Accounting Review, 48(1), 102-116.

Radhouane, I., Nekhili, M., Nagati, H., \& Paché, G. (2018). Customer-related performance and the relevance of environmental reporting. Journal of Cleaner Production, 190, 315-329.

Schneider, T., Michelon, G., \& Paananen, M. (2018). Environmental and social matters in mandatory corporate reporting: An academic note: ENVIRONMENTAL AND SOCIAL MATTERS IN MANDATORY CORPORATE REPORTING. Accounting Perspectives, 17(2), 275-305. doi:10.1111/1911-3838.12173

Schultz, K. \& Williamson, P. (2005). Gaining competitive advantage in a carbon constrained world: strategies for European Business. European Management Journal, 23(4), 383-391.

Stanny, E. \& Ely, K., 2008, Corporate Environmental Disclosures about the Effects of Climate Change, Corporate Social Responsibility and Environmental Management, Vol. 15, No. 6, pp. 338-348.

Switzer L.N., \& Cao, Y. (2011). Shareholder interests vs board of director members' interests and company performance: a new look. Review of Accounting and Finance 10: 228 -245

United Nations Framework Convention on Climate Change. (2014). The Paris Agreement. Retrieved from https://ec.europa.eu/clima/policies/international/negotiations/paris_en 
Wittneben, B. B., \& Kiyar, D. (2009). Climate change basics for managers. Management Decision, 47(7), 1122-1132. doi:10.1108/00251740910978331 


\section{Glossary}

\begin{tabular}{|c|c|c|}
\hline Terms & Definitions & Page \\
\hline $\begin{array}{l}\text { Disclosures } \\
\text { on Climate } \\
\text { Change } \\
\text { Issues } \\
\text { (DCCI) }\end{array}$ & $\begin{array}{l}\text { DCCI is the disclosures issues on the climate changes developed } \\
\text { for this study through content analysis. Content analysis is done on } \\
\text { the sustainability reports, annual reports, and annual information } \\
\text { forms of the sample companies. }\end{array}$ & $\begin{array}{l}3,5,25,27,32,33,41- \\
50\end{array}$ \\
\hline $\begin{array}{l}\text { Firm Value } \\
\text { (FV) }\end{array}$ & $\begin{array}{l}\text { Firm value is measured by the market to book assets ratio of the } \\
\text { sample firms in this study. However, the market to book equity is } \\
\text { also used to increase the robustness' of the firm value variable. }\end{array}$ & $5,22,25,42-50$ \\
\hline $\begin{array}{l}\text { Board } \\
\text { Shareholder } \\
\text { Confidence } \\
\text { Index(BSCI) }\end{array}$ & $\begin{array}{l}\text { The board of director's effectiveness is measured by the Board } \\
\text { Shareholders' Confidence index (BSCI). Clarkson Centre for } \\
\text { Business Ethics (CCBE) of Rothman School of University of } \\
\text { Toronto developed and measured the BSCI index. They annually } \\
\text { publish the BSCI rating for the listed companies of the S\& P or } \\
\text { TSX. }\end{array}$ & $5,21,25,32,41-50$ \\
\hline $\begin{array}{l}\text { Return on } \\
\text { Assets (ROA) }\end{array}$ & $\begin{array}{l}\text { Profitability is represented by return on assets. It is measured by } \\
\text { dividing the net income to the total assets of sample firms }\end{array}$ & $25,33,24,41-50$ \\
\hline $\begin{array}{l}\text { Return on } \\
\text { Equity (ROE) }\end{array}$ & $\begin{array}{l}\text { Profitability is also measured by return on equity. ROE is } \\
\text { measured here by dividing the net income to the equity of the } \\
\text { sample firms. }\end{array}$ & $25,34,41-50$ \\
\hline Leverage & $\begin{array}{l}\text { Leverage is the debt of the companies. In this research leverage is } \\
\text { measured by the ratio of total debt to stockholders' equity. }\end{array}$ & $25,335,35,41-50$ \\
\hline Size & $\begin{array}{l}\text { Size means the firm size of the sample companies. In this research } \\
\text { it is measured as the logarithm of total assets of the firms. }\end{array}$ & $25,34,41-50$ \\
\hline
\end{tabular}

